\title{
Prevalence of Cervical Spondylolisthesis in the Sagittal Plane Using Radiographic Imaging in a Pediatric Population: A Cross Sectional Analysis of Vertebral Subluxation
}

\author{
Curtis Fedorchuk ${ }^{1 *}$, Robert DeVon Comer ${ }^{1}$, Teri Lorencen Stockwell ${ }^{1}$, Jerome Stockwell ${ }^{1}$, Rachel \\ Stockwell $^{1}$, Douglas Frank Lightstone ${ }^{1}$ \\ 1. Institute for Spinal Health and Performance, Cumming, GA, USA
}
* Correspondence: Curtis Fedorchuk, D.C., Institute for Spinal Health and Performance, 460 Brannon Rd, Suite 101, Cumming, GA 30041, USA
(入cfedorchuk@comcast.net)

Radiology Case. 2021 Jun; 15(6):1-18 :: $\quad$ DOI: 10.3941/jrcr.v15i6.4280

\begin{abstract}
Introduction: Cervical Spondylolisthesis (CS) in children is under-studied. This cross-sectional study reports the CS prevalence in children. Materials \& Methods: Subjects were selected from a private practice. Inclusion criteria: 0-17 years of age; documented demographics and health complaints; neutral lateral cervical (NLC) radiographs; and CS. Exclusion criteria: pseudosubluxation. Results: 342 NLC radiographs were analyzed. 73 (21.3\%) had CS greater than $2.0 \mathrm{~mm} .42$ (57.5\%) had no musculoskeletal complaints. $8(2.3 \%)$ had the presence of a CS greater than $3.5 \mathrm{~mm} .5$ $(62.5 \%)$ had no musculoskeletal complaints. Discussion: Pediatric populations endure various traumas. Pediatric cervical spine biomechanics has an increased risk of upper cervical spine injury. Regular spinal radiographic exams may help identify serious spinal conditions in their presymptomatic state. Conclusion: CS in pediatric populations is under-studied. CS is present in children and adolescents with and without symptoms.
\end{abstract}

\section{ORIGINAL RESEARCH}

\section{INTRODUCTION}

Spondylolisthesis is a vertebral subluxation that refers to a significant transverse structural displacement of one vertebral body on the vertebra below. Spondylolisthesis is detected, analyzed, measured, and monitored by radiograph. It is considered uncommon in the cervical spine when compared to the lumbar spine and is now being recognized as an understudied condition [1].
Spondylolisthesis is categorized into two main types: congenital and acquired spondylolisthesis. Congenital spondylolisthesis is caused by a failure in development in the vertebrae. Acquired spondylolisthesis refers to a defect in the pars interarticularis caused by degeneration, trauma, pathology, and (or) surgical complications [2].

"Cervical spondylolisthesis prevalence has been reported as low as $5.2 \%$ to $12 \%$, whereas that of lumbar spondylolisthesis is $15.8 \%$ to $19.7 \%$. Thus, cervical 
spondylolisthesis has received less attention than lumbar spondylolisthesis" [3]. The male-to-female ratio is 1.5 to 1 in grade 1 and 2.2 to 1 in grade 2 cervical spondylolisthesis (CS) and there is an increased prevalence after 60 years with a $33.3 \%$ prevalence in 20 to 59 years and $66.7 \%$ in 60 to 99 years of age [4]. CS in symptomatic patients was found to be $16.4 \%$ prevalence of grade 1 and $3.4 \%$ of grade 2 (Table 1). CS was graded and defined by the following criteria: grade 1 is defined as $2-3.5 \mathrm{~mm}$ of displacement and grade 2 is defined as displacement greater than $3.5 \mathrm{~mm}[1,5]$. "Patients with severe spondylolisthesis had unequivocal horizontal displacement of $3.5 \mathrm{~mm}$ or more, a criterion established by White et al. as suggestive of instability in the cervical spine, whereas those with moderate spondylolisthesis had horizontal displacement of 2.0-3.4 $\mathrm{mm}$, and those with mild spondylolisthesis had a horizontal displacement of less than $2.0 \mathrm{~mm}$ " [6]. White et al. further conclude that "the spine is unstable or on the brink of instability [when] more than 3.5 $\mathrm{mm}$ horizontal displacement of one vertebra in relation to an adjacent vertebra, anteriorly or posteriorly, measured on a resting lateral roentgenograms of the spine" [7].

Spondylolisthesis may present with or without pain in children and adolescents. Like scoliosis and other unstable, degenerative structural, spinal conditions, progression of spondylolisthesis occurs during the adolescent growth spurt [8]. "Cervical spondylolisthesis results in not only cervical pain but also radiculopathy or myelopathy as it progresses and thus should never be neglected. In the aging society, the number of patients with degenerative changes of the cervical spine is expected to increase" [9]. CS creates a scissoring effect with the transverse structural displacement of one vertebra on another resulting in a narrowing of the spinal canal at the intervertebral location [10]. CS is an indicator of cervical vertebral instability and associated with disc degeneration and facet joint arthropathy.

Treatment choices for a child with spondylolisthesis include observation, limitation of activities, exercises, bracing, casting, and surgery (repair of a pars defect, fusion, decompression, and reduction of the slippage) [11]. Corrective chiropractic care involving chiropractic adjustments, exercises, and traction have been shown to reduce cervical spondylolisthesis [10]. Regardless, restoration of global sagittal balance of the spine and pelvic alignment is paramount in the treatment of any spinal deformity [12].

Spondylolisthesis is an understudied condition in pediatric populations. There are studies that report on prevalence of lumbar spondylolisthesis in pediatric populations. However, these studies focus on the lumbosacral spine $[11,13]$. There does not appear to be any epidemiology study reporting on CS in pediatric populations outside of isolated cases [14]. The objective of this cross-sectional study is to report on the prevalence of CS in the sagittal plane in a pediatric population.

\section{MATERIALS \& METHODS}

\section{Review of Literature}

A review of literature was performed researching cervical spondylolisthesis in children, adolescents, and pediatric populations. Search terms Cervical Spondylolisthesis AND Children OR Adolescents OR Pediatrics OR Pediatric Populations in Google Scholar, PubMed, and ScienceDirect research databases. The results showed many studies and reports. However, there did not seem to be any epidemiology studies reporting on CS in pediatric populations. Epidemiology studies reporting on spondylolisthesis and pediatric populations focus on the lumbosacral spine. There were case studies that reported on isolated incidents of CS in pediatrics. However, this cross-sectional study appears to be the first to report on CS in a larger pediatric population.

\section{Study Design}

Subjects in this cross-sectional study were selected from a radiographic records review of a private practice in Cumming, GA, USA. Subjects that met inclusion criteria were selected from a total of 342 pediatric patients (184 females and 158 males). This study is Institutional Review Board approved and all procedures performed in this study involving the 342 human participants were in accordance with the ethical standards of the 1964 Helsinki declaration and its later amendments or comparable ethical standards. Informed consent was obtained from all individual participants included in the study.

\section{Inclusion/Exclusion Criteria}

Inclusion criteria was that subjects needed to: be 17 years of age or younger; have their demographics (age, sex, height, weight, and race) and health complaints documented; have neutral lateral radiographs taken at the time of their documented demographics and health complaints; and have intervertebral, segmental translation in the sagittal plane $(\mathrm{Tz})$ within the cervical spine (C2-C7). Exclusion criteria was any segmental translation in the sagittal plane that qualified as a pseudosubluxation. The CS needed to qualify as a true vertebral subluxation. Suspected CS at C2-C3 were screened using the posterior cervical line (Swischuk line) [15]. "The posterior cervical line [Swischuk line] is a line drawn through the posterior arches of $\mathrm{C} 1$ and $\mathrm{C} 3$ on a lateral cervical spine radiograph. In physiological displacement of $\mathrm{C} 2$ on $\mathrm{C} 3$ [C2C3 pseudosubluxation] the anterior cortex of the posterior arch of $\mathrm{C} 2$ is allowed to pass through, touch or lie up to $1 \mathrm{~mm}$ behind the posterior cervical line" [15].

\section{Measurements}

This study involves the analysis of upright, weight bearing, neutral lateral cervical (NLC) radiographs of 342 pediatric patients. Radiographs were analyzed using PostureRay ${ }^{\circledR}$ X-Ray Electronic Medical Records Software (PostureCo, Inc., Trinity, FL, USA) according to the Harrison Posterior Tangent method for spine views in the sagittal place $[16,17]$. Spondylolisthesis was measured in millimeters as the perpendicular translational distance between the posterior tangent line of the inferior vertebra to the posterior inferior aspect of the adjacent superior vertebra (Figure 1) and was defined as greater than or equal to $2.0 \mathrm{~mm}$ of translational 
distance [9]. Normal cervical sagittal spinal alignment maintains a circular lordotic curvature and a perpendicular translational distance of $0.0 \mathrm{~mm}$ between the posterior tangential line of the inferior vertebra to the posterior inferior aspect of the adjacent superior vertebra (Figure 2) [18].

\section{Analysis}

Subject demographic and radiographic analysis data were exported to a Microsoft Excel (Microsoft Corporation, Redmond, WA, USA) spreadsheet and analyzed using Microsoft Power BI (Microsoft Corporation, Redmond, WA, USA). Microsoft Power BI is an analytics software that provides data warehouse capabilities including data preparation, data discovery, and interactive visualizations that can generate reports.

Microsoft Power BI allowed for the discovery and reporting of the following aspects of this study:

- $|\mathrm{CS}|>2.0 \mathrm{~mm}$

- $|\mathrm{CS}|>3.5 \mathrm{~mm}$

- $\mathrm{CS}<-2.0 \mathrm{~mm}$

- $\mathrm{CS}<-3.5 \mathrm{~mm}$;

- $\mathrm{CS}>2.0 \mathrm{~mm}$

- $\mathrm{CS}>3.5 \mathrm{~mm}$;

- > $2|\mathrm{CS}|>2.0 \mathrm{~mm}$

- > $2|\mathrm{CS}|>3.5 \mathrm{~mm}$

- $|\mathrm{CS}|>2.0 \mathrm{~mm}$ with and without health complaint(s);

- $|\mathrm{CS}|>3.5 \mathrm{~mm}$ with and without health complaints(s).

\section{RESULTS}

A total of 342 patients' NLC radiographs were analyzed. There were 184 females and 158 males from 4 through 17 years of age with a mean age of $12.3 \pm 6.8$ years $(95 \% \mathrm{CI})$, a mean height of $157.4 \pm 35.2 \mathrm{~cm}(95 \% \mathrm{CI})$ and weight of 62.2 $+42.0 \mathrm{~kg}(95 \% \mathrm{CI})$.

\section{CS Measuring Greater Than $2.0 \mathrm{~mm}$}

Seventy-three of 342 radiographs revealed the presence of a CS greater than $2.0 \mathrm{~mm}(21.3 \%)$ (Figure3) comprised of 4 anterolistheses and 101 retrolistheses (105 CS in total). There were 41 females and 32 males from 4 through 17 years of age with a mean age of $12.1 \pm 6.4$ years $(95 \% \mathrm{CI})$, a mean height of $157.8 \pm 29.4 \mathrm{~cm}(95 \% \mathrm{CI})$ and weight of $60.9 \pm 38.6 \mathrm{~kg}$ $(95 \% \mathrm{CI})$. Within the 73 radiographs, $41 \mathrm{CS}$ were located at C2-C3, 21 at C3-C4, 19 at C4-C5, 11 at C5-C6, and 8 at C6C7. The greatest number of pediatric patients with $\mathrm{CS}$ measuring greater than $2.0 \mathrm{~mm}$ were between 9 and 16 years of age with the greatest number of CS at 10, 14, and 16 years of age (Figure 4).

Fifty of 342 radiographs (30 female and 20 male patients) revealed the presence of $1 \mathrm{CS}$ greater than $2.0 \mathrm{~mm}(14.6 \%)$ per pediatric patient comprised of 1 anterolistheses and 49 retrolistheses (50 CS in total). Within the 50 radiographs, 26 CS were located at $\mathrm{C} 2-\mathrm{C} 3,9$ at $\mathrm{C} 3-\mathrm{C} 4,8$ at $\mathrm{C} 4-\mathrm{C} 5,3$ at $\mathrm{C5}-$ $\mathrm{C} 6$, and 4 at $\mathrm{C} 6-\mathrm{C} 7$. The greatest number of pediatric patients with $1 \mathrm{CS}$ measuring greater than $2.0 \mathrm{~mm}$ were between 9 and
16 years of age with the greatest number of $\mathrm{CS}$ at 9,12 , and 16 years of age (Figure 5).

Fifteen of 342 radiographs ( 8 female and 7 male patients) revealed the presence of 2 CS greater than $2.0 \mathrm{~mm}(4.4 \%)$ per pediatric patient comprised of 3 anterolistheses and 27 retrolistheses (30 CS in total). Within the 15 radiographs, $8 \mathrm{CS}$ were located at $\mathrm{C} 2-\mathrm{C} 3,11$ at $\mathrm{C} 3-\mathrm{C} 4,6$ at $\mathrm{C} 4-\mathrm{C} 5,4$ at $\mathrm{C} 5-\mathrm{C} 6$, and 1 at $\mathrm{C} 6-\mathrm{C} 7$. The greatest number of pediatric patients with 2 CS measuring greater than $2.0 \mathrm{~mm}$ were between 10 and 14 years of age with the greatest number of CS at 10 and 14 years of age (Figure 6)

Seven of 342 radiographs ( 3 female and 4 male patients) revealed the presence of $3 \mathrm{CS}$ greater than $2.0 \mathrm{~mm}(2.0 \%)$ per pediatric patient comprised of 0 anterolistheses and 21 retrolistheses (21 CS in total). Within the 15 radiographs, $6 \mathrm{CS}$ were located at $\mathrm{C} 2-\mathrm{C} 3,5$ at $\mathrm{C} 3-\mathrm{C} 4,4$ at $\mathrm{C} 4-\mathrm{C} 5,4$ at $\mathrm{C} 5-\mathrm{C} 6$, and 2 at C6-C7. The greatest number of pediatric patients with $3 \mathrm{CS}$ measuring greater than $2.0 \mathrm{~mm}$ were between 10 and 14 years of age with the greatest number of CS at 10 years of age (Figure 7).

One of 342 radiographs ( 0 female and 1 male patients) revealed the presence of $4 \mathrm{CS}$ greater than $2.0 \mathrm{~mm}(0.3 \%)$ per pediatric patient comprised of 0 anterolistheses and 4 retrolistheses (4 CS in total). Within the 15 radiographs, $6 \mathrm{CS}$ were located at $\mathrm{C} 2-\mathrm{C} 3,5$ at $\mathrm{C} 3-\mathrm{C} 4,4$ at $\mathrm{C} 4-\mathrm{C} 5,4$ at $\mathrm{C} 5-\mathrm{C} 6$, and 2 at $\mathrm{C} 6-\mathrm{C} 7$. The pediatric patient with $3 \mathrm{CS}$ measuring greater than $2.0 \mathrm{~mm}$ was 10 years of age (Figure 8 ).

Within the 73 radiographs of pediatric patients with 105 CS greater than $2.0 \mathrm{~mm}, 22$ patients $(30.1 \%)$ reported head and(or) neck musculoskeletal complaints. Of those 22 patients, 9 reported only head and(or) neck musculoskeletal complaints. Nine patients reported mid-back, low back, and(or) pelvic musculoskeletal complaints without head and(or) neck musculoskeletal complaints. Forty-two patients (57.5\%) reported no musculoskeletal complaints (Table 2).

\section{CS Measuring Greater Than $3.5 \mathrm{~mm}$}

Eight of 342 radiographs revealed the presence of a CS greater than $3.5 \mathrm{~mm}(2.3 \%)$ (Figure 9) comprised of 1 anterolistheses and 9 retrolistheses (10 CS in total). There were 5 females and 3 males from 4 through 17 years of age with a mean age of $11.5 \pm 6.2$ years $(95 \% \mathrm{CI})$, a mean height of $160.0 \pm 28.2 \mathrm{~cm}(95 \% \mathrm{CI})$ and weight of $60.6 \pm 39.4 \mathrm{~kg}$ $(95 \% \mathrm{CI})$. Within the 8 radiographs, $3 \mathrm{CS}$ were located at $\mathrm{C} 2-$ $\mathrm{C} 3,2$ at $\mathrm{C} 3-\mathrm{C} 4,1$ at $\mathrm{C} 4-\mathrm{C} 5,3$ at $\mathrm{C} 5-\mathrm{C} 6$, and 1 at C6-C7. The greatest number of pediatric patients with $\mathrm{CS}$ measuring greater than $3.5 \mathrm{~mm}$ were between 12 and 14 years of age with the greatest number of CS at 12 years of age (Figure 10).

Seven of 342 radiographs (4 female and 3 male patients) revealed the presence of $1 \mathrm{CS}$ greater than $3.5 \mathrm{~mm}(14.6 \%)$ per pediatric patient comprised of 1 anterolistheses and 6 retrolistheses (7 CS in total). Within the 7 radiographs, $3 \mathrm{CS}$ were located at $\mathrm{C} 2-\mathrm{C} 3,1$ at $\mathrm{C} 3-\mathrm{C} 4,1$ at $\mathrm{C} 4-\mathrm{C} 5,2$ at $\mathrm{C} 5-\mathrm{C} 6$, and 0 at C6-C7. The greatest number of pediatric patients with $1 \mathrm{CS}$ measuring greater than $3.5 \mathrm{~mm}$ were between 12 and 14 
years of age with the greatest number of CS at 12 years of age (Figure 11).

One of 342 radiographs ( 1 female and 0 male patients) revealed the presence of 4 CS greater than $3.5 \mathrm{~mm}(0.3 \%)$ per pediatric patient comprised of 0 anterolistheses and 4 retrolistheses (4 CS in total). Within the 1 radiograph, $0 \mathrm{CS}$ were located at $\mathrm{C} 2-\mathrm{C} 3,1$ at $\mathrm{C} 3-\mathrm{C} 4,0$ at $\mathrm{C} 4-\mathrm{C} 5,1$ at $\mathrm{C} 5-\mathrm{C} 6$, and 1 at C6-C7. The pediatric patient with 4 CS measuring greater than $3.5 \mathrm{~mm}$ was 8 years of age (Figure 12).

Within the 8 radiographs of pediatric patients with $10 \mathrm{CS}$ greater than $3.5 \mathrm{~mm}, 2$ patients (25.0\%) reported head and(or) neck musculoskeletal complaints. Of those 2 patients, 1 reported only head and(or) neck musculoskeletal complaints. One patient reported mid-back, low back, and(or) pelvic musculoskeletal complaints without head and(or) neck musculoskeletal complaints. Five patients $(62.5 \%)$ reported no musculoskeletal complaints (Table 2).

\section{C2-C3 Pseudosubluxation}

Pseudosubluxation is defined as a non-pathological anterolisthesis of $\mathrm{C} 2$ on $\mathrm{C} 3$ and described as a normal variant with no significant association with injury severity or outcome [15]. "Lack of awareness of the normal variation in the alignment of the upper cervical spine in children may lead to over diagnosis of significant injury" [15]. In a pseudosubluxation, the $\mathrm{C} 2$ body translates anteriorly on $\mathrm{C} 3$ but the $\mathrm{C} 2$ spinolaminar line does not cross the posterior cervical line (Swischuk line) from the posterior arch of $\mathrm{C} 1$ to that of C3 (Figure 13). Suspected CS at C2-C3 were screened using the posterior cervical line (Swischuk line). C2-C3 anterolistheses greater than $2.0 \mathrm{~mm}$ where the $\mathrm{C} 1-\mathrm{C} 3$ posterior cervical line passed through, touched, or lied $1 \mathrm{~mm}$ in front of the C2 spinolaminar line did not qualify as CS in this study. Within the 73 radiographs of pediatric patients with $105 \mathrm{CS}$ greater than $2.0 \mathrm{~mm}, 9$ patients $(12.3 \%)$ had $\mathrm{C} 2-\mathrm{C} 3$ pseudosubluxation which were not included in the data for CS prevalence.

\section{DISCUSSION}

This study shows that CS, even to the point of spinal instability and including multiple levels of CS, is present in children and adolescents with and without the presence of symptoms. Seventy-three of 342 radiographs revealed the presence of a CS greater than $2.0 \mathrm{~mm}(21.3 \%), 8$ radiographs revealed the presence of a CS greater than $3.5 \mathrm{~mm}(2.3 \%)$, and 9 radiographs revealed the presence of C2-C3 pseudosubluxation (12.3\%).

\section{Spinal Alignment and Posture}

Prevalence of CS may be more common than previously thought [1]. CS has been showed to be caused by abnormal sagittal cervical alignment, facet joint angles and arthrosis which alter cervical biomechanics. This leads to increased stress with cervical flexion and extension, damage to cervical discs and ligaments, and allows for instability and slippage to occur [19]. Woiciechowsky states that instability causes damage to the ligaments and the disc causing the vertebral body to horizontally displace [19]. Most of the time, neck pain is the first symptom [19]. If patients with neck pain are evaluated for instability before there is damage to the facet joints, ligaments, and discs, degenerative cervical spondylolisthesis may be slowed or prevented.

Jun et al. shows that anatomy has influence cervical spine sagittal alignment [20]. Jun et al. states that T1 slope is an important factor in the cervical sagittal alignment, which causes anterior translation of the vertebral body's center of gravity [20]. Increased mobility, sliding force, and loss of cervical lordosis cause stress at the disc and facet joints [20].

Degenerative changes in the cervical spine has been shown been shown to increase as the cervical sagittal alignment is altered. It is well documented in the literature that cervical lordosis is associated with nerve entrapment, pain, and degeneration of the cervical spine [20].

Restoration of global sagittal balance of the spine and pelvic alignment is paramount in the treatment of any spinal deformity [12].

\section{Epidemiology and Spinal Deformity}

The developing anatomy of the cervical spine in children increases the risk of injury of the upper cervical spine. The biomechanics of the pediatric cervical spine has the fulcrum of motion at the C2-C3 level as opposed to C5-C6 in the adult cervical spine. "The immature spine is hypermobile because of ligamentous laxity, shallow and angled facet joints, underdeveloped spinous processes, and physiologic anterior wedging of vertebral bodies, all of which contribute to high torque and shear forces acting on the $\mathrm{C} 1-\mathrm{C} 2$ region. Incomplete ossification of the odontoid process, a relatively large head, and weak neck muscles are other factors that predispose to instability of the pediatric cervical spine" [22]. Younger children are more likely to sustain an upper cervical spine injury located from the occiput to $\mathrm{C} 3$. These injuries are also associated with a high risk of neurologic damage [22].

Parents, guardians, and caregivers often seek healthcare treatment options for their children due to the presence of symptoms such as pain, discomfort, or abnormal posture. However, the reality is that children and adolescents are likely to endure any number of various forms of trauma. Birth trauma [23], unintentional falls [24], sports-related trauma [25], motor vehicle crash trauma [26], play-related trauma [27], childhood violence [28], and other trauma risks are ever present. A major problem is that many forms of childhood trauma are not reported and underestimated [29]. In some cases, only children are witness to the trauma. In other cases, the appearance of a lack of physical damage or an absence of symptoms following a trauma results in a lack of physical examination for many children following a trauma. Also, children are very resilient which may mask underlying risks and physical injuries that become evident later. "To remedy spine-related problems, assessments of X-ray images are essential to determine the spine and postural parameters" [30]. Further investigation into the sagittal spinal alignment of children and adolescents with or without symptoms may help to identify the precursors or presence of CS. Studying the prevalence of spinal deformity and vertebral subluxation, such 
as CS, in pediatric populations educates and informs parents, guardians, caregivers, healthcare providers, and healthcare policymakers to help treat and prevent degenerative spinal conditions for children and adolescents.

\section{Differential Diagnosis}

The differential diagnosis for CS includes cervical fracture, cervical canal stenosis, cervical disc degeneration, and cervical facet dislocation or arthropathy [31]. These conditions often present with the similar clinical symptoms, such as neck pain and radiculopathy. However, CS is often made worse with extension and can be asymptomatic (Table 1) $[31]$.

\section{Limitations}

While this study contains several patients $(n=342)$, the subjects may not represent the general population because they were recruited from one area in the United States and were patients presenting to a private practice. It is important to note, however, that not all the patients presented with pain in the cervical or thoracic region which allows for greater application. Second, in pediatric populations, physiological changes take place over shorter time intervals than in adulthood. Further studies should focus on more subjects with increased attention to the sub-groups of ages within the pediatric population. Third, this is a cross-sectional study. We cannot confirm a causal relationship involving CS. Fourth, more and less critical subjects might not have participated in our study. Fifth, we failed to evaluate dynamic instability of the cervical spine, which should be taken into consideration in CS evaluation.

\section{CONCLUSION}

At present, pediatric CS epidemiology does not seem to be represented in research. This cross-sectional study shows that CS in pediatric populations seems under-studied and needs greater attention. This study shows that CS, even to the point of spinal instability and including multiple levels of CS, is present in children and adolescents with and without the presence of symptoms. The data presented support further investigation into the sagittal spinal alignment of children and adolescents with or without symptoms to identify the precursors or presence of CS

Future prospective studies involving larger populations, multiple locations, long-term follow-ups, and more anthropometric and clinical data will shed more light on the epidemiology of CS and the associated functional and symptomatic effects and pathologies.

\section{TEACHING POINT}

Cervical spondylolistheses greater than $2.0 \mathrm{~mm}(21.3 \%)$ and $3.5 \mathrm{~mm}(2.3 \%)$, even to the point of spinal instability and including multiple levels of cervical spondylolisthesis, are present in children and adolescents with and without the presence of symptoms. The data presented support further investigation into the sagittal spinal alignment of children and adolescents with or without symptoms to identify the precursors or presence of cervical spondylolisthesis.

\section{REFERENCES}

1. Suzuki A, Daubs MD, Inoue $\mathrm{H}$, et al. Prevalence and motion characteristics of degenerative cervical spondylolisthesis in the symptomatic adult. Spine (Phila $\mathrm{Pa}$ 1976). 2013;38(17):E1115-20. PMID: 23680839.

2. Sedney CL, Mcconda DB, Daffner SD. Natural history of spondylolysis and spondylolisthesis. Semin Spine Surg. 2014;26(4):214-218.

3. Murakami K, Nagata K, Hashizume H, et al. Prevalence of cervical anterior and posterior spondylolisthesis and its association with degenerative cervical myelopathy in a general population. Sci Rep. 2020;10(1):10455. PMID: 32591548.

4. Kopacz KJ, Connolly PJ. The prevalence of cervical spondylolisthesis. Orthopedics. 1999 Jul;22(7):677-9. PMID: 10418863.

5. Ward CV, Latimer B. Human evolution and the development of spondylolysis. Spine (Phila Pa 1976). 2005;30(16):1808-14. PMID: 16103848.

6. Kawasaki M, Tani T, Ushida T, Ishida K. Anterolisthesis and retrolisthesis of the cervical spine in cervical spondylotic myelopathy in the elderly. J Orthop Sci. 2007;12(3):207-213. PMID: 17530371.

7. White AA III, Johnson RM, Panjabi MM, Southwick WO. Biomechanical analysis of clinical stability in the cervical spine. Clin Orthop. 1975;109:85-96.

8. Lonstein JE. Spondylolisthesis in children: cause, natural history, and management. Spine. 1999;24(24):2640-8. PMID: 10635527.

9. Murakami K, Nagata K, Hashizume H, et al. Prevalence of cervical anterior and posterior spondylolisthesis and its association with degenerative cervical myelopathy in a general population. Sci Rep. 2020;10(1):10455. PMID: 32591548.

10. Fedorchuk C, Lightstone DF, Comer RD, et al. Improvements in cervical spinal canal diameter and neck disability following correction of cervical lordosis and cervical spondylolistheses using Chiropractic BioPhysics technique: a case series. J Radiol Case Rep. 2020;14(4):21-37. PMID: 33082920

11. Lonstein JE. Spondylolisthesis in children: cause, natural history, and management. Spine. 1999;24(24):2640-8. PMID: 10635527.

12. Tsirikos AI, Garrido EG. Spondylolysis and spondylolisthesis in children and adolescents. J Bone Joint Surg Br. 2010;92(6):751-9. PMID: 20513868. 
13. Laurent LE, Einola S. Spondylolisthesis in Children and Adolescents. Acta Orthop Scand. 1961;31(1):45-64. PMID: 13759516.

14. Robson MJ, Brown LM, Sharrard WJ. Cervical spondylolisthesis and other skeletal abnormalities in Rubinstein-Taybi syndrome. The Journal of bone and joint surgery. British volume. 1980 Aug;62(3):297-9. PMID: 7410460

15. Shaw M, Burnett H, Wilson A, et al. Pseudosubluxation of $\mathrm{C} 2$ on $\mathrm{C} 3$ in polytraumatized children--prevalence and significance. Clin Radiol. 1999;54(6):377-380. PMID: 10406338

16. Jackson BL, Harrison DD, Robertson GA, et al. Chiropractic Biophysics Lateral Cervical Film Analysis J Manipulative Physiol Ther. 1993;16(6):384-391. PMID: 8409786

17. Harrison DE, Harrison DD, Cailliet R, et al. Cobb Method or Harrison Posterior Tangent Method: Which is Better for Lateral Cervical Analysis? Spine. 2000;25(16):2072-2078. PMID: 10954638

18. Harrison DD, Janik TJ, Troyanovich SJ, Harrison DE, Colloca CJ. Evaluation of the assumptions used to derive an ideal normal cervical spine model. J Manipulative Physiol Ther. 1997;20(4):246-256. PMID: 9168409.

19. Woiciechowsky C, Thomale UW, Kroppenstedt SN. Degenerative spondylolisthesis of the cervical spine-symptoms and surgical strategies depending on disease progress. Eur Spine J. 2004;13(8):680-4. PubMed PMID: 15221569

20. Jun HS, Kim JH, Ahn JH, et al. T1 slope and degenerative cervical spondylolisthesis. Spine (Phila $\mathrm{Pa}$ 1976). 2015;40(4):E220-6. PMID: 25423304.

21. Okada E, Matsumoto M, Ichihara D, et al. Does the sagittal alignment of the cervical spine have an impact on disk degeneration? Minimum 10-year follow-up of asymptomatic volunteers. Eur Spine J. 2009;18(11):1644-51. PMID: 19609784.

22. Lustrin ES, Karakas SP, Ortiz AO, et al. Pediatric cervical spine: normal anatomy, variants, and trauma. Radiographics. 2003;23(3):539-560. PMID: 12740460.

23. Sauber-Schatz EK, Markovic N, Weiss HB, et al. Descriptive epidemiology of birth trauma in the United States in 2003. Paediatr Perinat Epidemiol. 2010;24(2):116-124. PMID: 20415766.

24. Khambalia A, Joshi P, Brussoni M, et al. Risk factors for unintentional injuries due to falls in children aged 0-6 years: a systematic review. Inj Prev. 2006;12(6):378-81. PMID: 17170185

25. Pfister $T$, Pfister $K$, Hagel $B$, et al. The incidence of concussion in youth sports: a systematic review and meta- analysis. Br J Sports Med. 2016;50(5):292-297. PMID: 26626271.

26. Srinivasan S, Chang T. Diagnosis and management of motor vehicle trauma in children: an evidence-based review. Pediatr Emerg Med Pract. 2013;10(8):1-26. PMID: 24151662.

27. Korhonen L, Salokorpi N, Suo-Palosaari M, et al. Severe Trampoline Injuries: Incidence and Risk Factors in Children and Adolescents. Eur J Pediatr Surg. 2018;28(6):529-533. PMID: 29166677.

28. Saunders BE, Adams ZW. Epidemiology of traumatic experiences in childhood. Child Adolesc Psychiatr Clin N Am. 2014;23(2):167-184. PMID: 24656575.

29. Arbogast KB, Curry AE, Pfeiffer MR, et al. Point of Health Care Entry for Youth With Concussion Within a Large Pediatric Care Network. JAMA Pediatr. 2016;170(7):e160294. PMID: 27244368.

30. Oakley PA, Cuttler JM, Harrison DE. X-Ray Imaging is Essential for Contemporary Chiropractic and Manual Therapy Spinal Rehabilitation: Radiography Increases Benefits and Reduces Risks. Dose Response. 2018;16(2):1559325818781437. PMID: 29977177.

31. Jiang SD, Jiang LS, Dai LY. Degenerative cervical spondylolisthesis: a systematic review. Int Orthop. 2011;35(6):869-75. PMID: 21264670. 


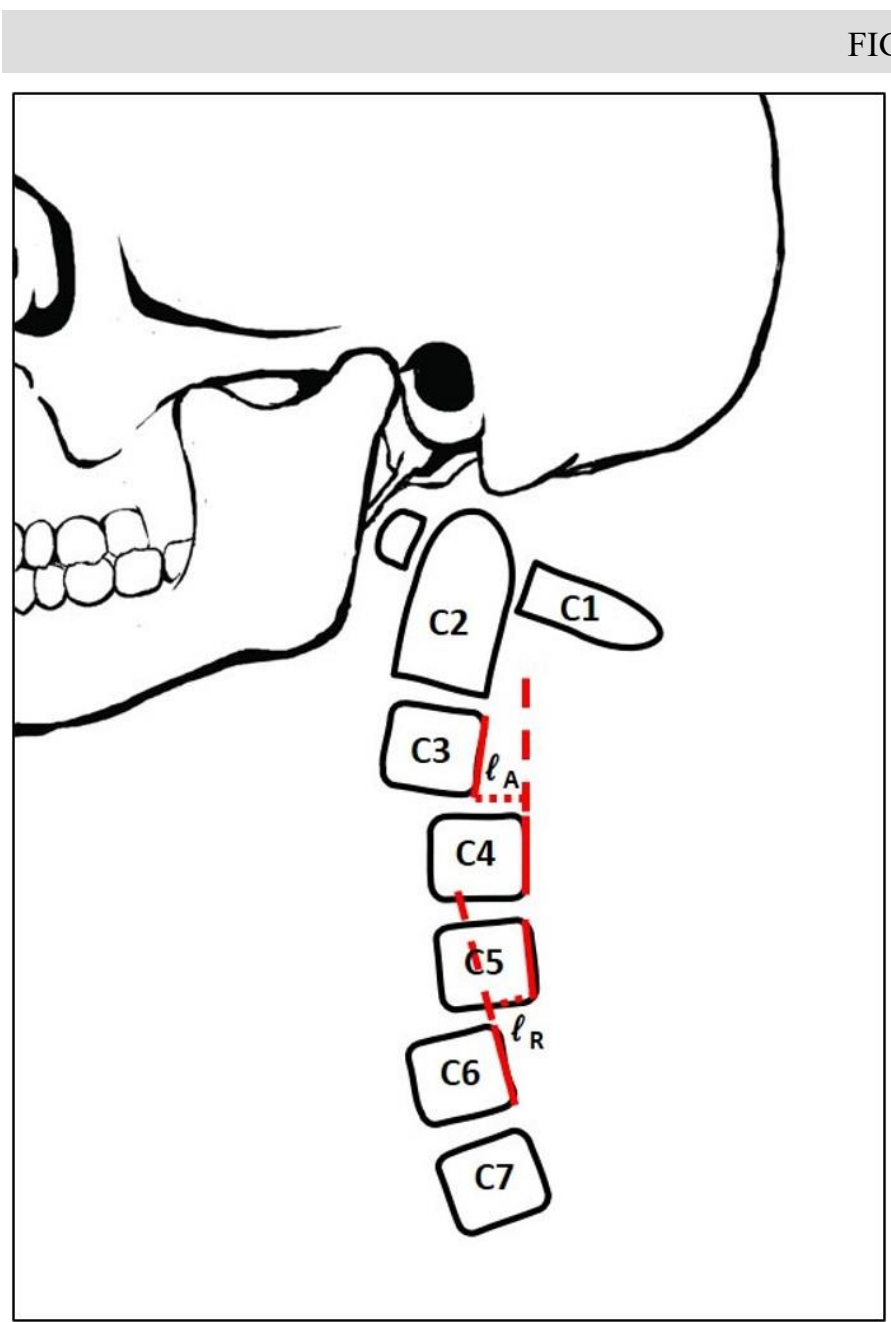

Figure 1: NLC Rendering Illustrating Anterior and Posterior CS and Method of Measuring the Sagittal Translation of One Cervical Vertebra on Another in CS

Image Features: The first through seventh cervical vertebrae are labelled $\mathrm{C} 1-\mathrm{C} 7$. The solid red line represents the actual posterior tangent lines of the $\mathrm{C} 3, \mathrm{C} 4, \mathrm{C} 5$, and $\mathrm{C} 6$ vertebrae. The dashed red line represents an extension of the posterior tangent lines of C4 and C6 vertebrae. The dotted red line represents the perpendicular distance from the posterior tangent of the inferior vertebra in a CS to the posterior, inferior aspect of the adjacent superior vertebra in a CS. $\ell$ A represents the length of the segmental anterior translation in an anterolisthesis at C3 (a CS where the superior vertebra moves anterior to the inferior vertebra). $\ell \mathrm{R}$ represents the length of the segmental posterior translation in a retrolisthesis at C5 (a $\mathrm{CS}$ where the superior vertebra moves posterior to the inferior vertebra).

Findings: CS is measured in millimeters as the perpendicular translational distance between the posterior tangential line of the inferior vertebra to the posterior inferior aspect of the adjacent superior vertebra.

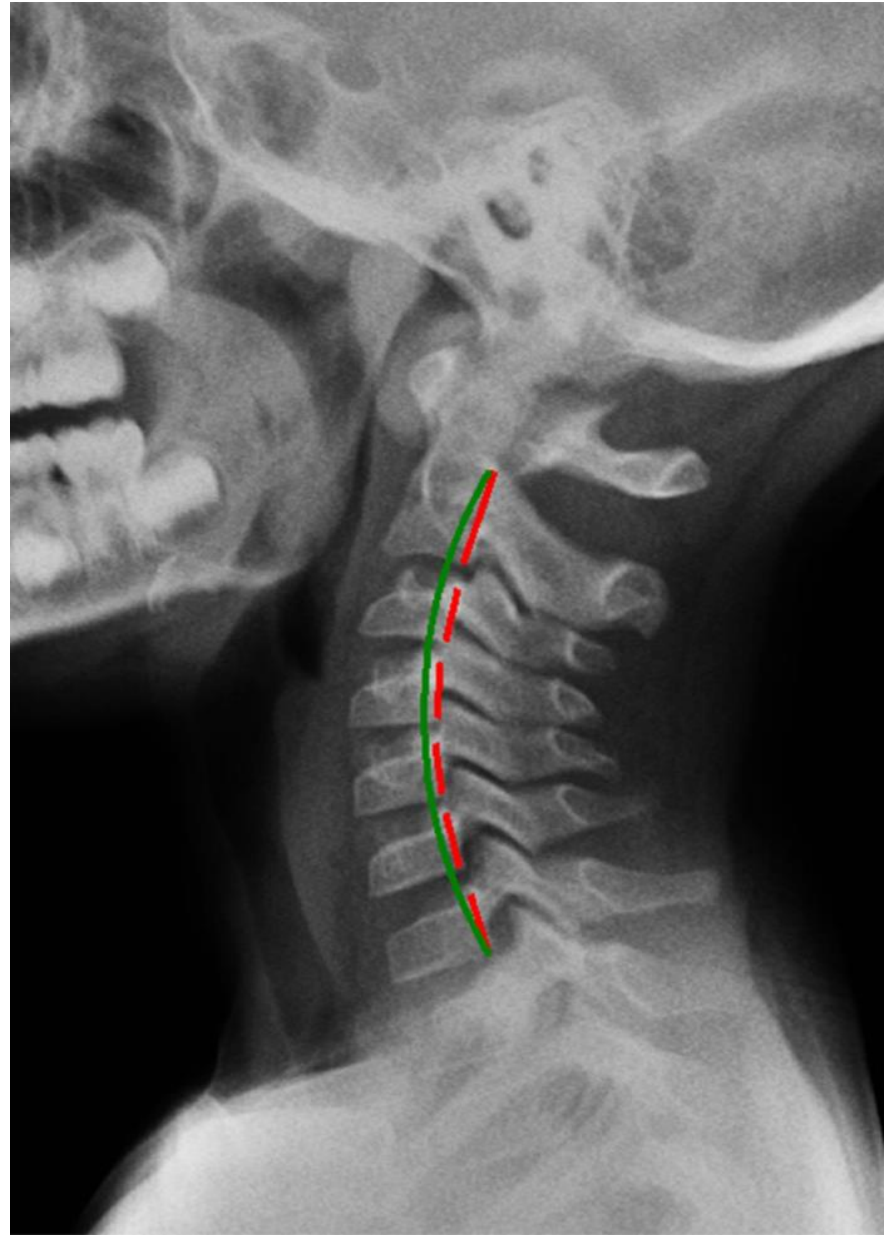

Figure 2: NLC Radiograph of a Pediatric Patient with a Normal Cervical Alignment

Description: 8-year-old male with no reported symptoms or history of trauma.

Image Features: The green line represents a normal, ideal cervical alignment. The red line represents the actual posterior tangent lines of the $\mathrm{C} 2-\mathrm{C} 7$ vertebrae.

Findings: NLC image shows normal cervical alignment, cervical curvature $\mathrm{C} 2-\mathrm{C} 7$ measures $-21.8^{\circ}\left(-22.5^{\circ}\right.$ is ideal $), \mathrm{Tz}$ C2-C7 measures $-0.5 \mathrm{~mm}(0.0 \mathrm{~mm}$ is ideal $),|\mathrm{STz}| \mathrm{C} 2-\mathrm{C} 7$ measurements $<0.3 \mathrm{~mm}(0.0 \mathrm{~mm}$ is ideal $)$.

Technique: $30 \mathrm{mAs}, 200 \mathrm{~mA}, 76 \mathrm{kVp}, 72$ " focal-film distance (FFD), Central Ray (CR) at C4. 


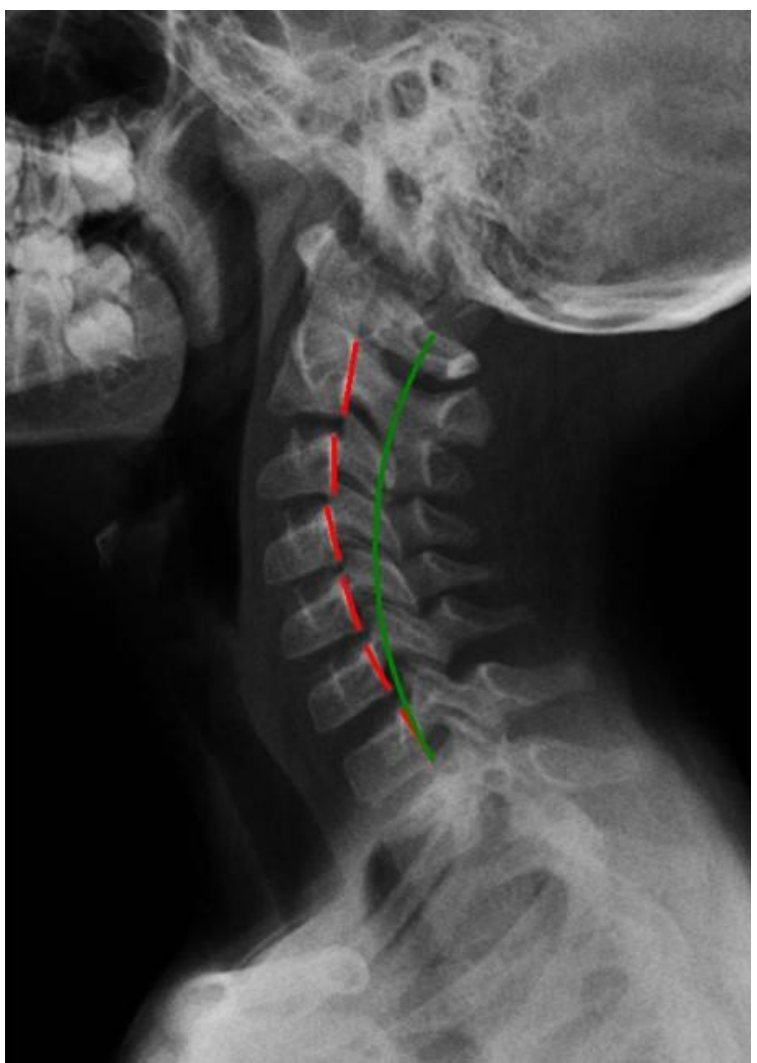

Figure 3 (left): NLC Radiograph of a Pediatric Patient with a CS Measuring Greater than $2.0 \mathrm{~mm}$

Description: 12-year-old female with reported headaches and neck pain and no reported history of trauma.

Image Features: The green line represents a normal, ideal cervical alignment. The red line represents the actual posterior tangent lines of the $\mathrm{C} 2-\mathrm{C} 7$ vertebrae.

Findings: NLC image shows cervical curvature C2-C7 measures $-41.7^{\circ}\left(21.5^{\circ}\right.$ is ideal), $\mathrm{Tz} \mathrm{C} 2-\mathrm{C} 7$ measures -16.6 $\mathrm{mm}(0.0 \mathrm{~mm}$ is ideal), STz measurements of C2-C3, C3-C4, C4-5, C5-C6, and C6-C7 are -2.9 mm, -2.5 mm, -1.5 mm, -1.0 $\mathrm{mm}$, and $-0.7 \mathrm{~mm}$ respectively $(0.0 \mathrm{~mm}$ is ideal and CS is greater than $2.0 \mathrm{~mm}$ ).

Technique: 30 mAs, $200 \mathrm{~mA}, 76 \mathrm{kVp}, 72 " \mathrm{FFD}, \mathrm{CR}$ at C4.

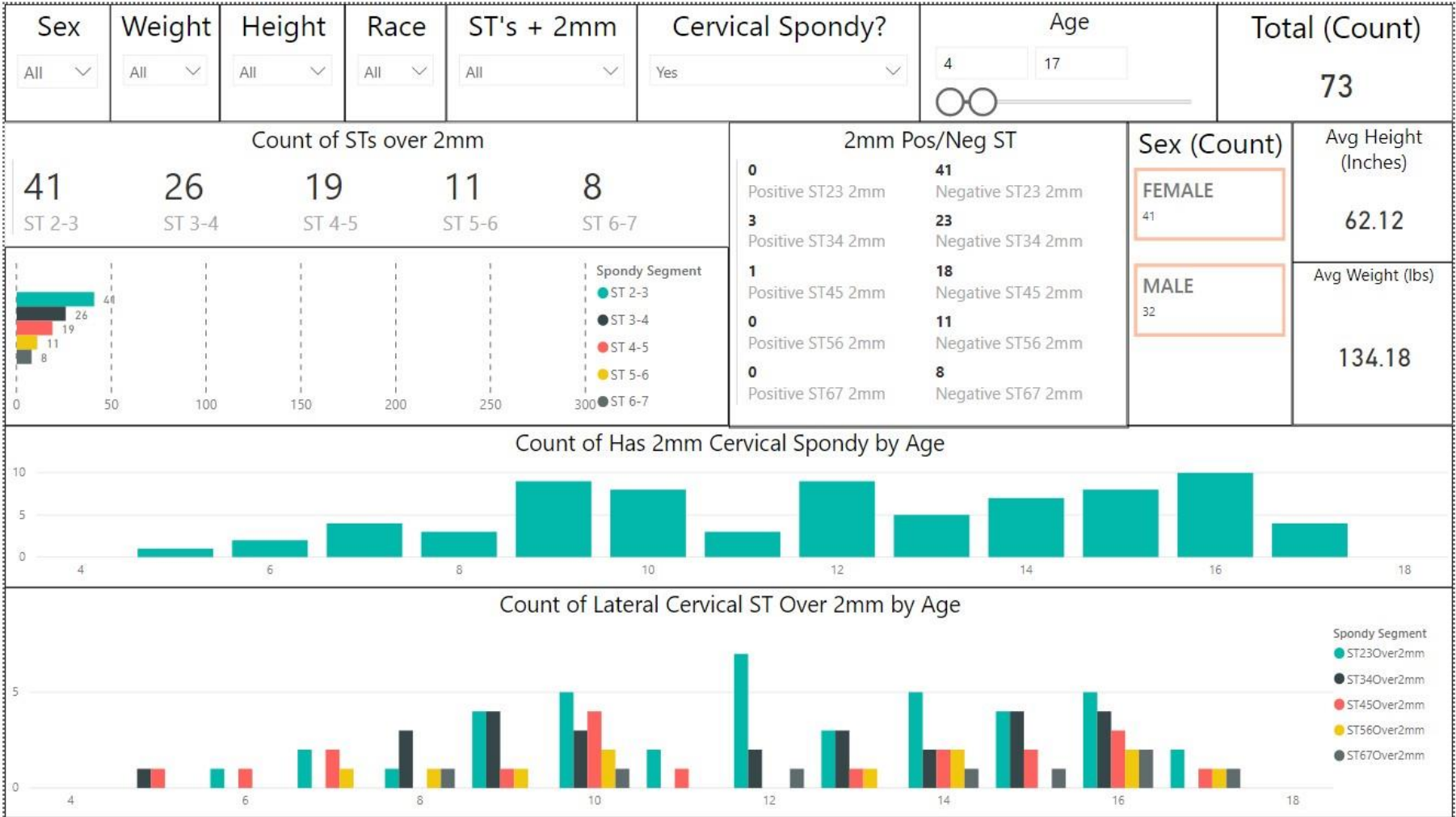

Figure 4: Pediatric Patients with CS Measuring Greater than $2.0 \mathrm{~mm}$

Image Features: This is a Microsoft Power BI interactive visualizations of pediatric patients with all CS measuring greater than $2.0 \mathrm{~mm}$. Pediatric patients with CS measuring greater than $2.0 \mathrm{~mm}$ of any sex, weight, height, and race between the ages of 0 through 17 years of age (the youngest age in this dataset is 4 years). This visualization provides counts of CS over 2.0 mm by cervical segments involved, age of the pediatric patients, and counts of CS over $2.0 \mathrm{~mm}$ by cervical segments involved as well as by age of the pediatric patients.

Findings: 73/342 radiographs (41 female and 32 male patients) revealed the presence of a CS greater than $2.0 \mathrm{~mm}(21.3 \%)$ comprised of 4 anterolistheses and 101 retrolistheses (105 CS in total). Within the 73 radiographs, $41 \mathrm{CS}$ were located at C2-C3, 21 at $\mathrm{C} 3-\mathrm{C} 4,19$ at $\mathrm{C} 4-\mathrm{C} 5,11$ at $\mathrm{C} 5-\mathrm{C} 6$, and 8 at C6-C7. The greatest number of pediatric patients with CS measuring greater than $2.0 \mathrm{~mm}$ were between 9 and 16 years of age with the greatest number of CS at 10, 14, and 16 years of age. 


\begin{tabular}{|c|c|c|c|c|c|c|c|c|c|c|}
\hline \multirow{2}{*}{$\begin{array}{l}\text { Sex } \\
\text { All } v\end{array}$} & \multirow{2}{*}{$\begin{array}{l}\text { Weight } \\
\text { All } \vee\end{array}$} & Height & \multirow{2}{*}{$\begin{array}{l}\text { Race } \\
\text { All } v\end{array}$} & \multicolumn{2}{|c|}{$\mathrm{ST}$ 's $+2 \mathrm{~mm}$} & \multicolumn{2}{|c|}{ Cervical Spondy? } & Age & & \multirow{2}{*}{$\begin{array}{c}\text { Total (Count) } \\
50\end{array}$} \\
\hline & & All $\quad v$ & & 1 & $\checkmark$ & Yes & $\checkmark$ & ${ }^{4} \mathrm{O}^{17}$ & 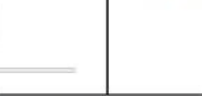 & \\
\hline \multicolumn{7}{|c|}{ Count of STs over $2 \mathrm{~mm}$} & \multicolumn{2}{|c|}{$2 \mathrm{~mm}$ Pos/Neg ST } & Sex (Count) & $\begin{array}{l}\text { Avg Height } \\
\text { (Inches) }\end{array}$ \\
\hline $\begin{array}{l}26 \\
\text { ST 2-3 }\end{array}$ & $\begin{array}{l}9 \\
\text { ST 3-4 }\end{array}$ & \multicolumn{2}{|c|}{$\begin{array}{l}8 \\
\text { ST 4-5 }\end{array}$} & $\begin{array}{l}3 \\
\text { ST 5-6 }\end{array}$ & $\begin{array}{l}4 \\
\text { ST 6-7 }\end{array}$ & & \multirow{2}{*}{$\begin{array}{l}0 \\
\text { Positive ST23 2mm } \\
\mathbf{1} \\
\text { Positive ST } 342 \mathrm{~mm} \\
\mathbf{0} \\
\text { Positive ST45 } 2 \mathrm{~mm} \\
\mathbf{0} \\
\text { Positive ST } 562 \mathrm{~mm} \\
0 \\
\text { Positive ST67 } 2 \mathrm{~mm}\end{array}$} & \multirow{2}{*}{$\begin{array}{l}26 \\
\text { Negative ST23 2mm } \\
8 \\
\text { Negative ST34 } 2 \mathrm{~mm} \\
8 \\
\text { Negative ST } 4552 \mathrm{~mm} \\
3 \\
\text { Negative ST56 } 2 \mathrm{~mm} \\
4 \\
\text { Negative S } 5672 \mathrm{~mm}\end{array}$} & \begin{tabular}{|l|} 
FEMALE \\
30
\end{tabular} & $\begin{array}{l}\text { (Inches) } \\
62.26\end{array}$ \\
\hline & 100 & 150 & 200 & 250 & 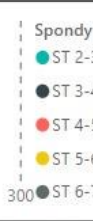 & & & & $\begin{array}{l}\text { MALE } \\
20\end{array}$ & $\begin{array}{c}\text { Avg Weight (lbs) } \\
134.42\end{array}$ \\
\hline \multicolumn{11}{|c|}{ Count of Has $2 \mathrm{~mm}$ Cervical Spondy by Age } \\
\hline & & 8 & & & & & 12 & & 16 & 18 \\
\hline \multicolumn{11}{|c|}{ Count of Lateral Cervical ST Over $2 \mathrm{~mm}$ by Age } \\
\hline & & & & & & & & & & 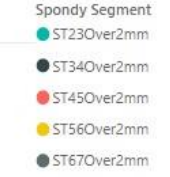 \\
\hline
\end{tabular}

Figure 5: Pediatric Patients with 1 CS Measuring Greater than $2.0 \mathrm{~mm}$

Image Features: This is a Microsoft Power BI interactive visualizations of pediatric patients with $1 \mathrm{CS}$ measuring greater than 2.0 $\mathrm{mm}$. Pediatric patients with $1 \mathrm{CS}$ measuring greater than $2.0 \mathrm{~mm}$ of any sex, weight, height, and race between the ages of 0 through 17 years of age (the youngest age in this dataset is 4 years) were included. This visualization provides counts of CS over $2.0 \mathrm{~mm}$ by cervical segments involved, age of the pediatric patients, and counts of CS over $2.0 \mathrm{~mm}$ by cervical segments involved as well as by age of the pediatric patients.

Findings: 50/342 radiographs (30 female and 20 male patients) revealed the presence of 1 CS greater than $2.0 \mathrm{~mm}(14.6 \%)$ per pediatric patient comprised of 1 anterolistheses and 49 retrolistheses (50 CS in total). Within the 50 radiographs, 26 CS were located at $\mathrm{C} 2-\mathrm{C} 3,9$ at $\mathrm{C} 3-\mathrm{C} 4,8$ at $\mathrm{C} 4-\mathrm{C} 5,3$ at $\mathrm{C} 5-\mathrm{C} 6$, and 4 at $\mathrm{C} 6-\mathrm{C} 7$. The greatest number of pediatric patients with 1 CS measuring greater than $2.0 \mathrm{~mm}$ were between 9 and 16 years of age with the greatest number of CS at 9,12, and 16 years of age. 


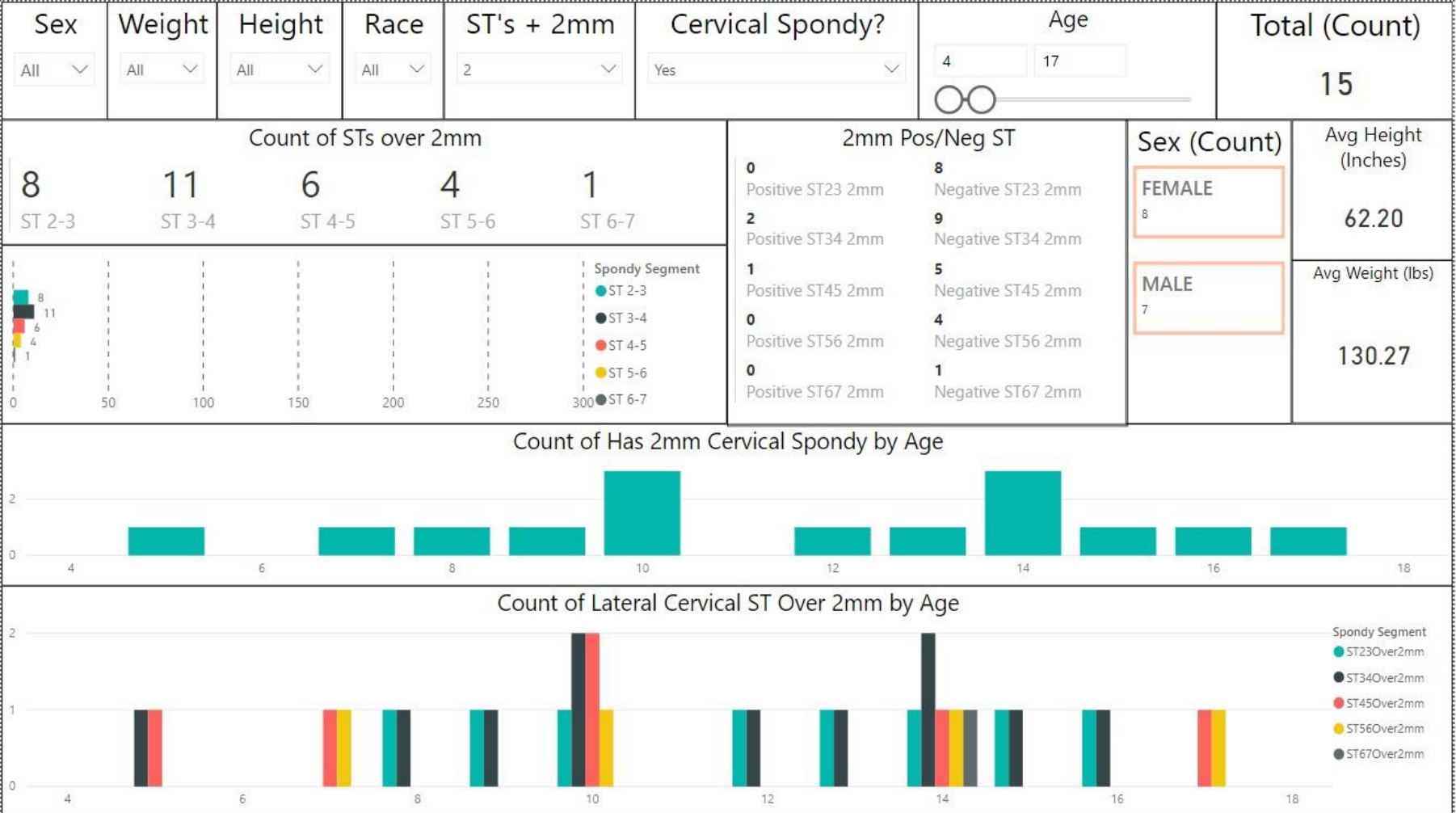

Figure 6: Pediatric Patients with 2 CS Measuring Greater than $2.0 \mathrm{~mm}$

Image Features: This is a Microsoft Power BI interactive visualizations of pediatric patients with 2 CS measuring greater than 2.0 $\mathrm{mm}$. Pediatric patients with $2 \mathrm{CS}$ measuring greater than $2.0 \mathrm{~mm}$ of any sex, weight, height, and race between the ages of 0 through 17 years of age (the youngest age in this dataset is 4 years) were included. This visualization provides counts of CS over $2.0 \mathrm{~mm}$ by cervical segments involved, age of the pediatric patients, and counts of CS over $2.0 \mathrm{~mm}$ by cervical segments involved as well as by age of the pediatric patients.

Findings: $15 / 342$ radiographs ( 8 female and 7 male patients) revealed the presence of 2 CS greater than $2.0 \mathrm{~mm}(4.4 \%)$ per pediatric patient comprised of 3 anterolistheses and 27 retrolistheses (30 CS in total). Within the 15 radiographs, 8 CS were located at $\mathrm{C} 2-\mathrm{C} 3,11$ at $\mathrm{C} 3-\mathrm{C} 4,6$ at $\mathrm{C} 4-\mathrm{C} 5,4$ at $\mathrm{C} 5-\mathrm{C} 6$, and 1 at C6-C7. The greatest number of pediatric patients with 2 CS measuring greater than $2.0 \mathrm{~mm}$ were between 10 and 14 years of age with the greatest number of CS at 10 and 14 years of age. 


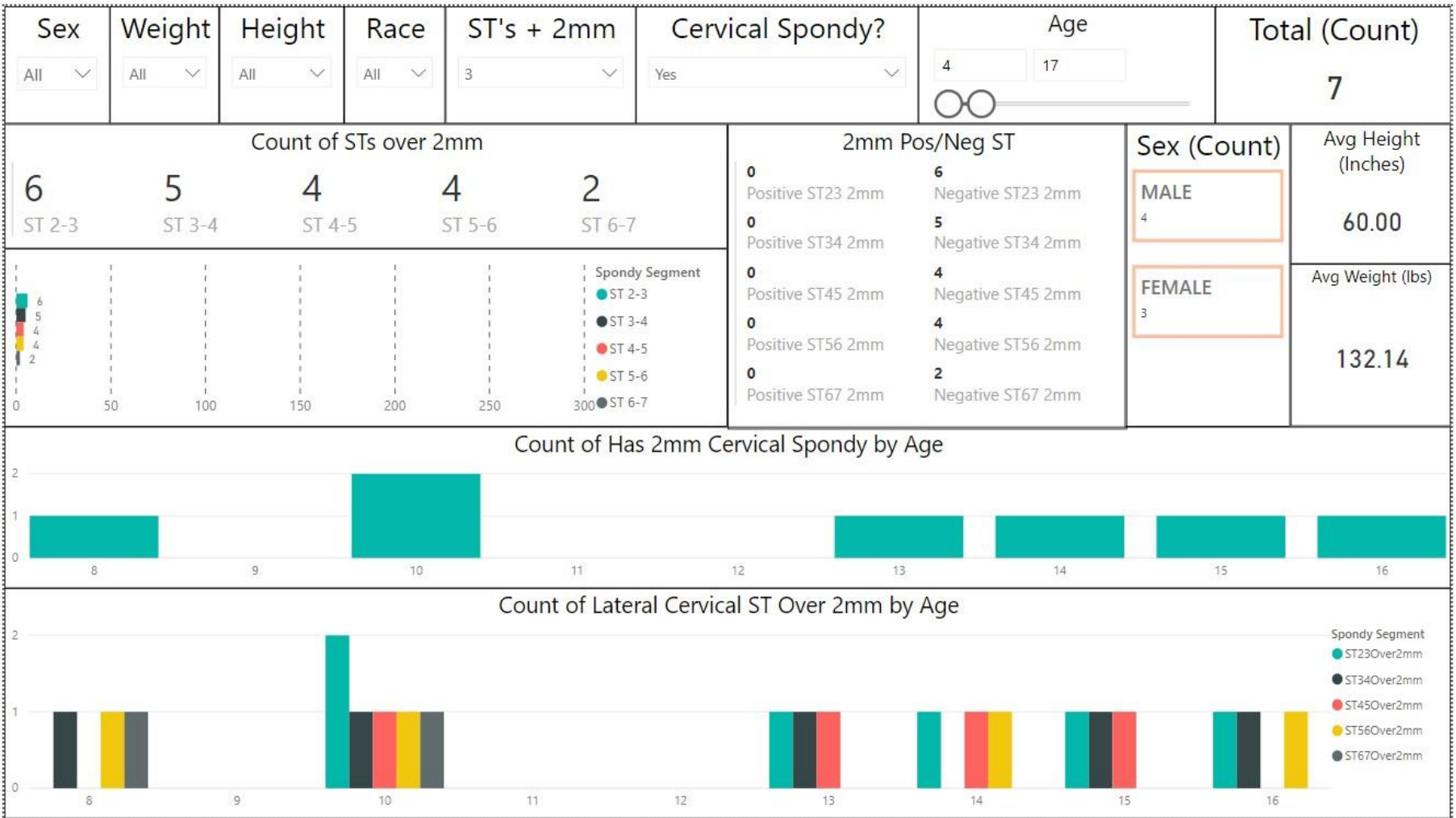

Figure 7: Pediatric Patients with 3 CS Measuring Greater than $2.0 \mathrm{~mm}$

Image Features: This is a Microsoft Power BI interactive visualizations of pediatric patients with 3 CS measuring greater than 2.0 $\mathrm{mm}$. Pediatric patients with $3 \mathrm{CS}$ measuring greater than $2.0 \mathrm{~mm}$ of any sex, weight, height, and race between the ages of 0 through 17 years of age (the youngest age in this dataset is 4 years) were included. This visualization provides counts of CS over $2.0 \mathrm{~mm}$ by cervical segments involved, age of the pediatric patients, and counts of CS over $2.0 \mathrm{~mm}$ by cervical segments involved as well as by age of the pediatric patients.

Findings: $7 / 342$ radiographs ( 3 female and 4 male patients) revealed the presence of 3 CS greater than $2.0 \mathrm{~mm}(2.0 \%)$ per pediatric patient comprised of 0 anterolistheses and 21 retrolistheses (21 CS in total). Within the 15 radiographs, 6 CS were located at $\mathrm{C} 2-\mathrm{C} 3,5$ at $\mathrm{C} 3-\mathrm{C} 4,4$ at $\mathrm{C} 4-\mathrm{C} 5,4$ at $\mathrm{C} 5-\mathrm{C} 6$, and 2 at $\mathrm{C} 6-\mathrm{C} 7$. The greatest number of pediatric patients with 3 CS measuring greater than $2.0 \mathrm{~mm}$ were between 10 and 14 years of age with the greatest number of CS at 10 years of age. 


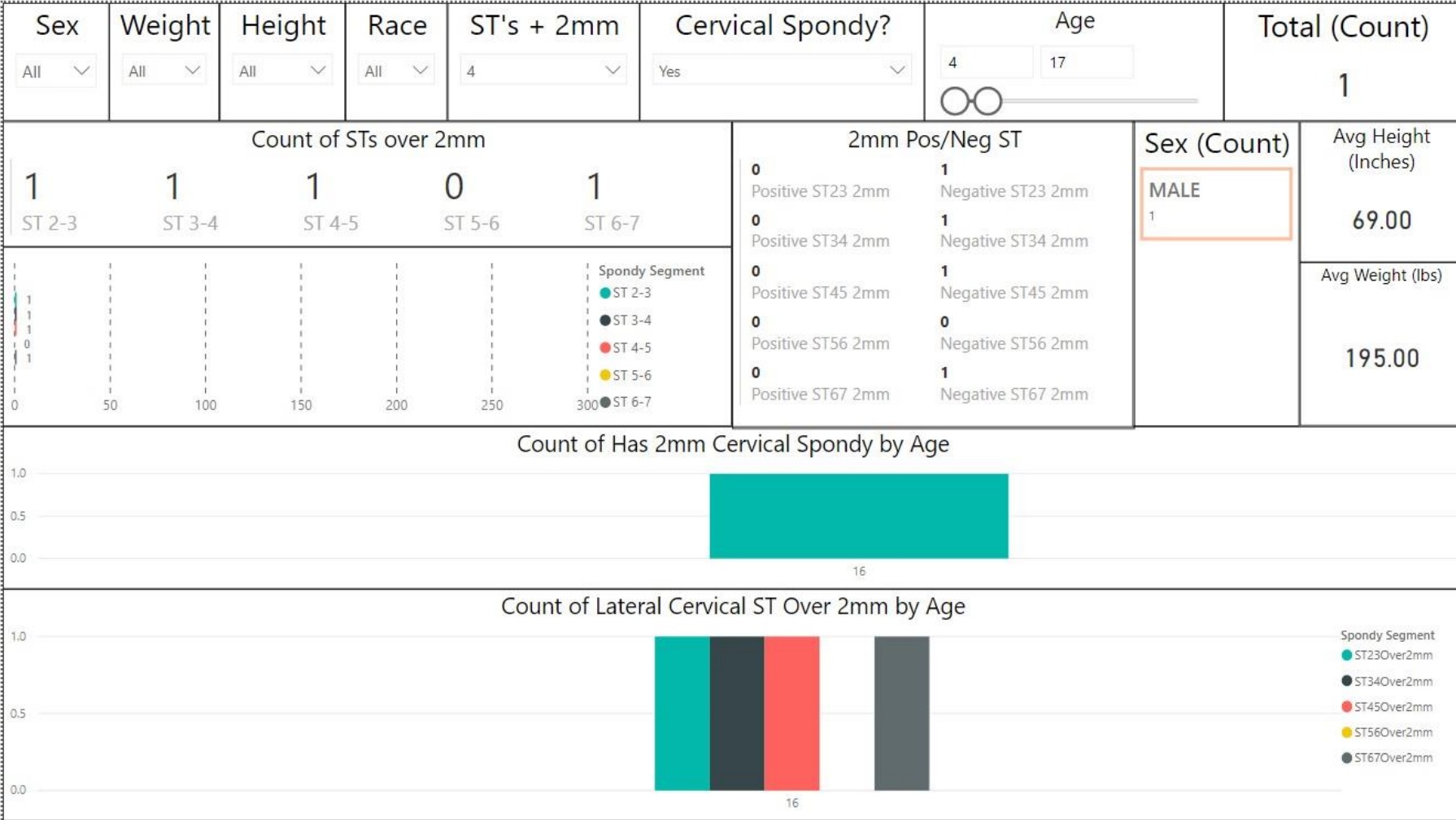

Figure 8: Pediatric Patients with 4 CS Measuring Greater than $2.0 \mathrm{~mm}$

Image Features: This is a Microsoft Power BI interactive visualizations of a pediatric patient with 4 CS measuring greater than $2.0 \mathrm{~mm}$. Pediatric patients with 4 CS measuring greater than $2.0 \mathrm{~mm}$ of any sex, weight, height, and race between the ages of 0 through 17 years of age (the youngest age in this dataset is 4 years) were included. This visualization provides counts of CS over $2.0 \mathrm{~mm}$ by cervical segments involved, age of the pediatric patient, and counts of CS over $2.0 \mathrm{~mm}$ by cervical segments involved as well as by age of the pediatric patient.

Findings: $1 / 342$ radiographs ( 0 female and 1 male patients) revealed the presence of $4 \mathrm{CS}$ greater than $2.0 \mathrm{~mm}(0.3 \%)$ per pediatric patient comprised of 0 anterolistheses and 4 retrolistheses (4 CS in total). Within the 15 radiographs, $6 \mathrm{CS}$ were located at $\mathrm{C} 2-\mathrm{C} 3,5$ at $\mathrm{C} 3-\mathrm{C} 4,4$ at $\mathrm{C} 4-\mathrm{C} 5,4$ at $\mathrm{C} 5-\mathrm{C} 6$, and 2 at C6-C7. The pediatric patient with $3 \mathrm{CS}$ measuring greater than $2.0 \mathrm{~mm}$ was 10 years of age. 


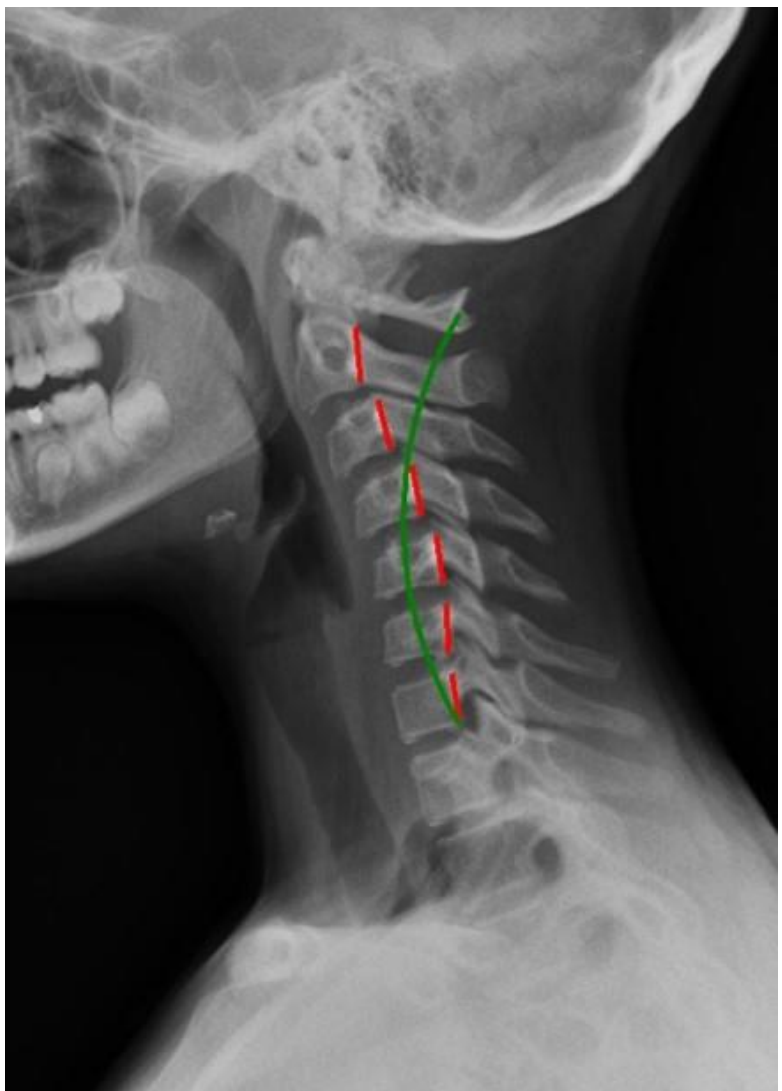

Figure 9 (left): NLC Radiograph of a Pediatric Patient with a CS Measuring Greater than $3.5 \mathrm{~mm}$

Description: 13-year-old female with reported neck pain following a traumatic fall while horseback riding

Image Features: The green line represents a normal, ideal cervical alignment. The red line represents the actual posterior tangent lines of the $\mathrm{C} 2-\mathrm{C} 7$ vertebrae.

Findings: NLC image shows cervical curvature $\mathrm{C} 2-\mathrm{C} 7$ measures $-3.4^{\circ}\left(-25.3^{\circ}\right.$ is ideal $), \mathrm{Tz} \mathrm{C} 2-\mathrm{C} 7$ is $23.9 \mathrm{~mm}(0.0$ $\mathrm{mm}$ is ideal), STz measurements of $\mathrm{C} 2-\mathrm{C} 3, \mathrm{C} 3-\mathrm{C} 4, \mathrm{C} 4-5, \mathrm{C} 5-$ C6, and C6-C7 are $1.6 \mathrm{~mm}, 3.6 \mathrm{~mm}, 2.0 \mathrm{~mm}, 0.2 \mathrm{~mm}$, and 0.6 $\mathrm{mm}$ respectively $(0.0 \mathrm{~mm}$ is ideal and CS is greater than 2.0 $\mathrm{mm})$.

Technique: $30 \mathrm{mAs}, 200 \mathrm{~mA}, 76 \mathrm{kVp}, 72 " \mathrm{FFD}, \mathrm{CR}$ at C4

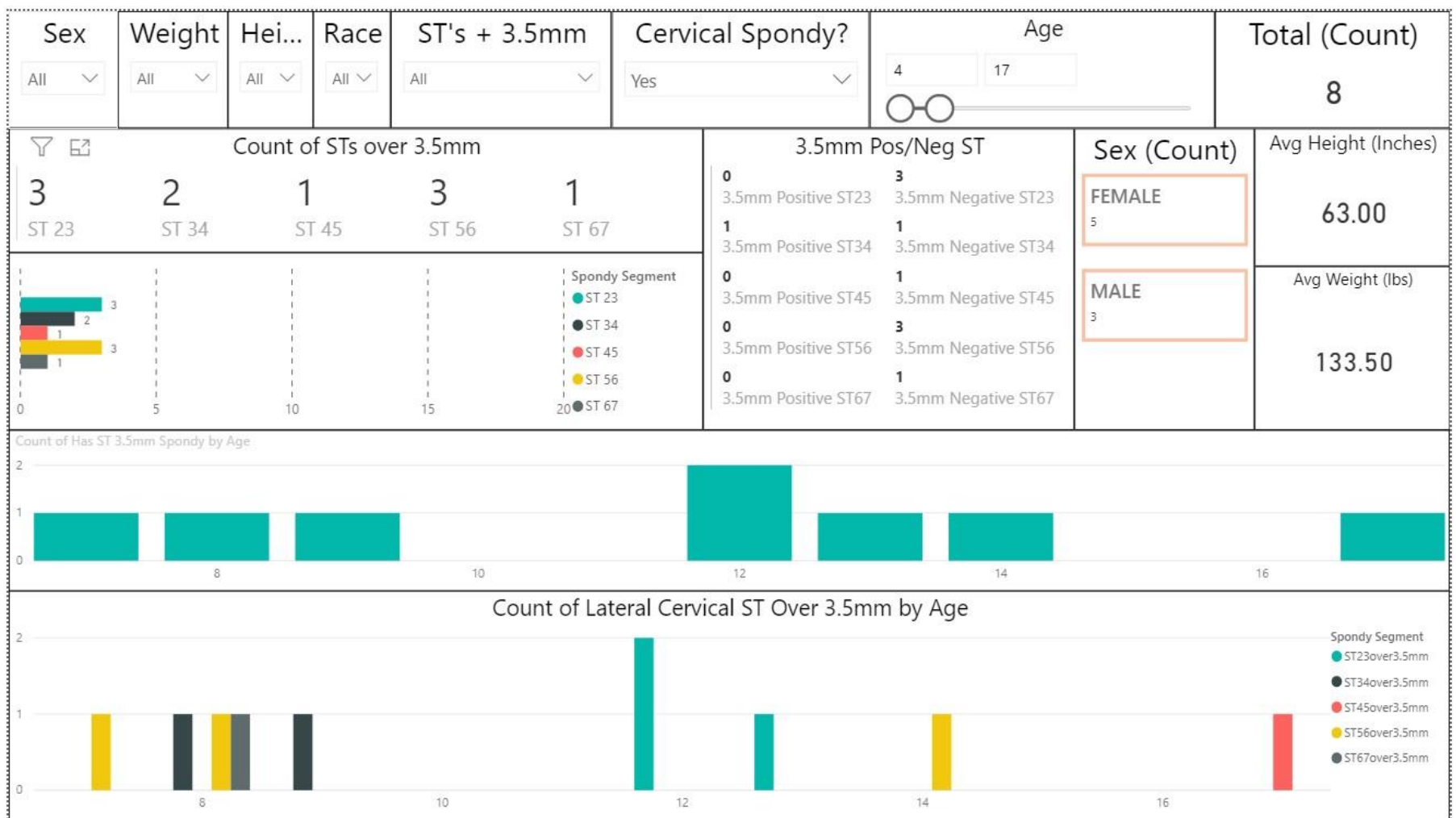

Figure 10: Pediatric Patients with CS Measuring Greater than $3.5 \mathrm{~mm}$

Image Features: This is a Microsoft Power BI interactive visualizations of pediatric patients with all CS measuring greater than $3.5 \mathrm{~mm}$. Pediatric patients with CS measuring greater than $3.5 \mathrm{~mm}$ of any sex, weight, height, and race between the ages of 0 through 17 years of age (the youngest age in this dataset is 4 years) were included. This visualization provides counts of CS over $3.5 \mathrm{~mm}$ by cervical segments involved, age of the pediatric patients, and counts of CS over $3.5 \mathrm{~mm}$ by cervical segments involved as well as by age of the pediatric patients.

Findings: 8/342 radiographs (5 female and 3 male patients) revealed the presence of a CS greater than $3.5 \mathrm{~mm}(2.3 \%)$ comprised of 1 anterolistheses and 9 retrolistheses (10 CS in total). Within the 8 radiographs, $3 \mathrm{CS}$ were located at $\mathrm{C} 2-\mathrm{C} 3,2$ at $\mathrm{C} 3-\mathrm{C} 4,1$ at C4-C5, 3 at C5-C6, and 1 at C6-C7. The greatest number of pediatric patients with CS measuring greater than $3.5 \mathrm{~mm}$ were between 12 and 14 years of age with the greatest number of CS at 12 years of age. 


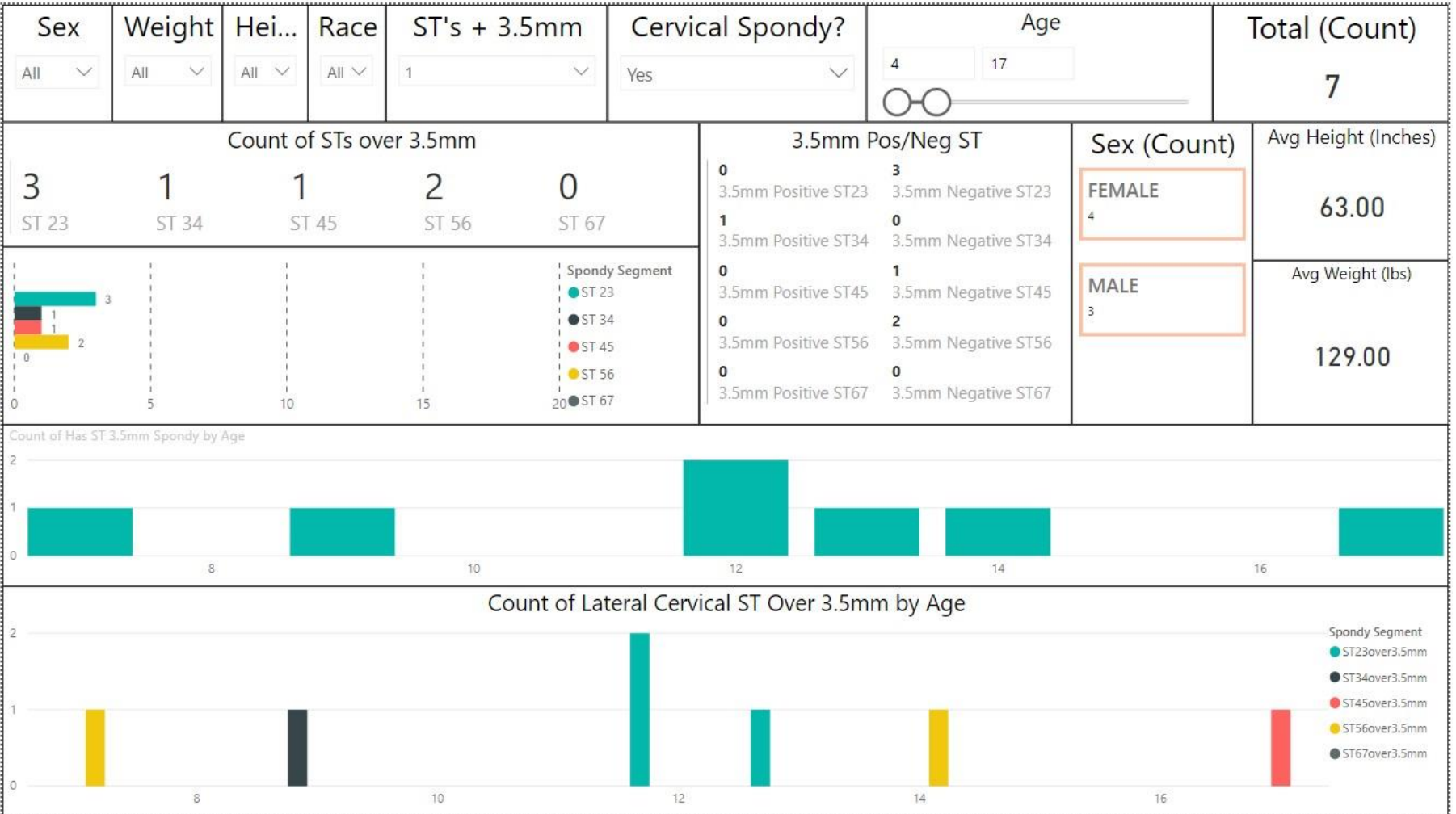

Figure 11: Pediatric Patients with 1 CS Measuring Greater than $3.5 \mathrm{~mm}$

Image Features: This is a Microsoft Power BI interactive visualizations of pediatric patients with 1 CS measuring greater than 3.5 $\mathrm{mm}$. Pediatric patients with $1 \mathrm{CS}$ measuring greater than $3.5 \mathrm{~mm}$ of any sex, weight, height, and race between the ages of 0 through 17 years of age (the youngest age in this dataset is 4 years) were included. This visualization provides counts of CS over $3.5 \mathrm{~mm}$ by cervical segments involved, age of the pediatric patients, and counts of CS over $3.5 \mathrm{~mm}$ by cervical segments involved as well as by age of the pediatric patients.

Findings: 7/342 radiographs (4 female and 3 male patients) revealed the presence of $1 \mathrm{CS}$ greater than $3.5 \mathrm{~mm}(14.6 \%$ ) per pediatric patient comprised of 1 anterolistheses and 6 retrolistheses (7 CS in total). Within the 7 radiographs, 3 CS were located at $\mathrm{C} 2-\mathrm{C} 3,1$ at $\mathrm{C} 3-\mathrm{C} 4,1$ at $\mathrm{C} 4-\mathrm{C} 5,2$ at $\mathrm{C} 5-\mathrm{C} 6$, and 0 at $\mathrm{C} 6-\mathrm{C} 7$. The greatest number of pediatric patients with $1 \mathrm{CS}$ measuring greater than $3.5 .0 \mathrm{~mm}$ were between 12 and 14 years of age with the greatest number of CS at 12 years of age. 


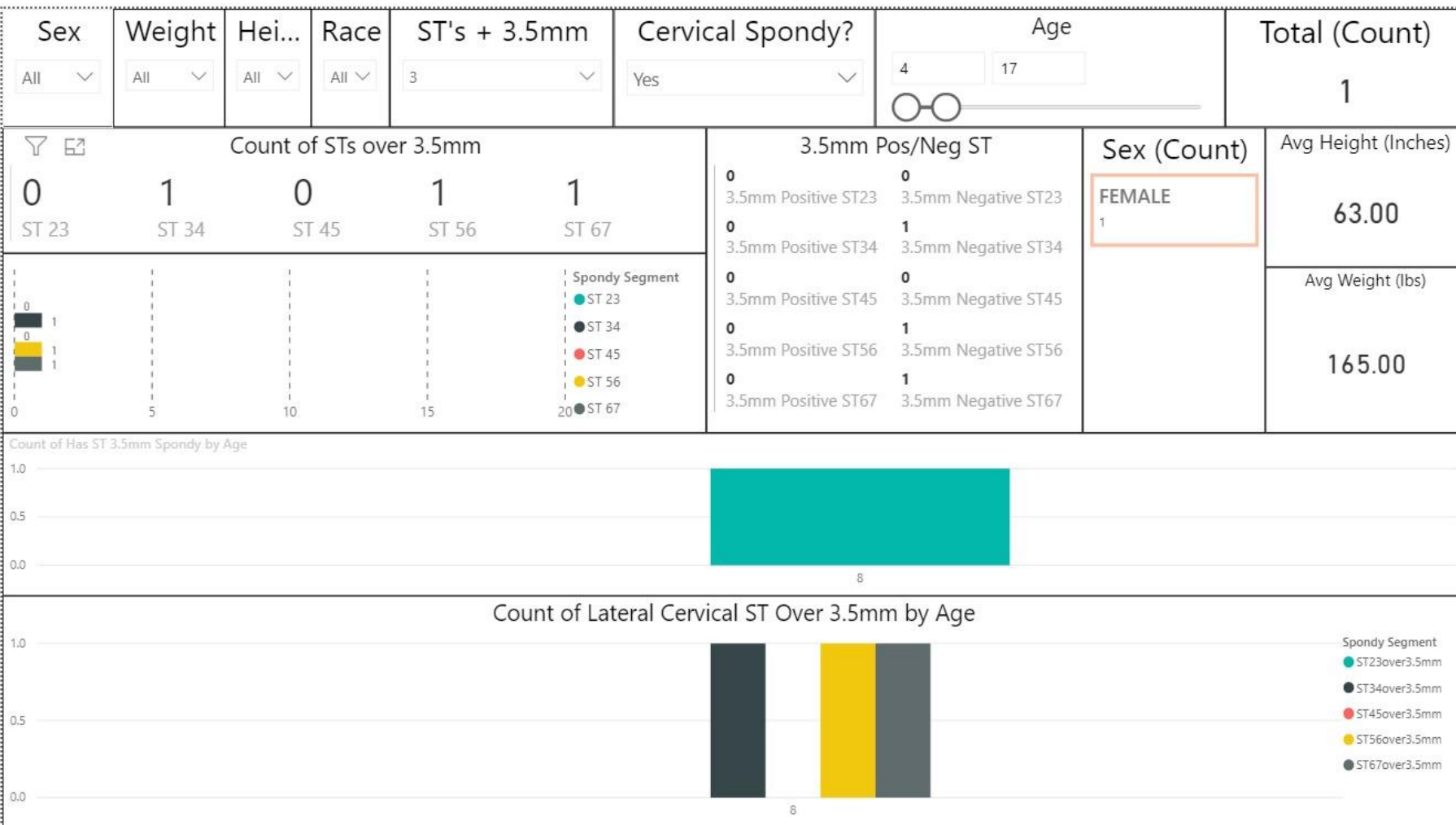

Figure 12: Pediatric Patient with 3 CS Measuring Greater than $3.5 \mathrm{~mm}$

Image Features: This is a Microsoft Power BI interactive visualizations of a pediatric patient with $3 \mathrm{CS}$ measuring greater than $3.5 \mathrm{~mm}$. Pediatric patients with $3 \mathrm{CS}$ measuring greater than $3.5 \mathrm{~mm}$ of any sex, weight, height, and race between the ages of 0 through 17 years of age (the youngest age in this dataset is 4 years) were included. This visualization provides counts of CS over $3.5 \mathrm{~mm}$ by cervical segments involved, age of the pediatric patient, and counts of CS over $3.5 \mathrm{~mm}$ by cervical segments involved as well as by age of the pediatric patient.

Findings: $1 / 342$ radiographs ( 1 female and 0 male patients) revealed the presence of 4 CS greater than $3.5 \mathrm{~mm}(0.3 \%)$ per pediatric patient comprised of 0 anterolistheses and 4 retrolistheses (4 CS in total). Within the 1 radiograph, 0 CS were located at $\mathrm{C} 2-\mathrm{C} 3,1$ at $\mathrm{C} 3-\mathrm{C} 4,0$ at $\mathrm{C} 4-\mathrm{C} 5,1$ at $\mathrm{C} 5-\mathrm{C} 6$, and 1 at $\mathrm{C} 6-\mathrm{C} 7$. The pediatric patient with $4 \mathrm{CS}$ measuring greater than $3.5 \mathrm{~mm}$ was 8 years of age.

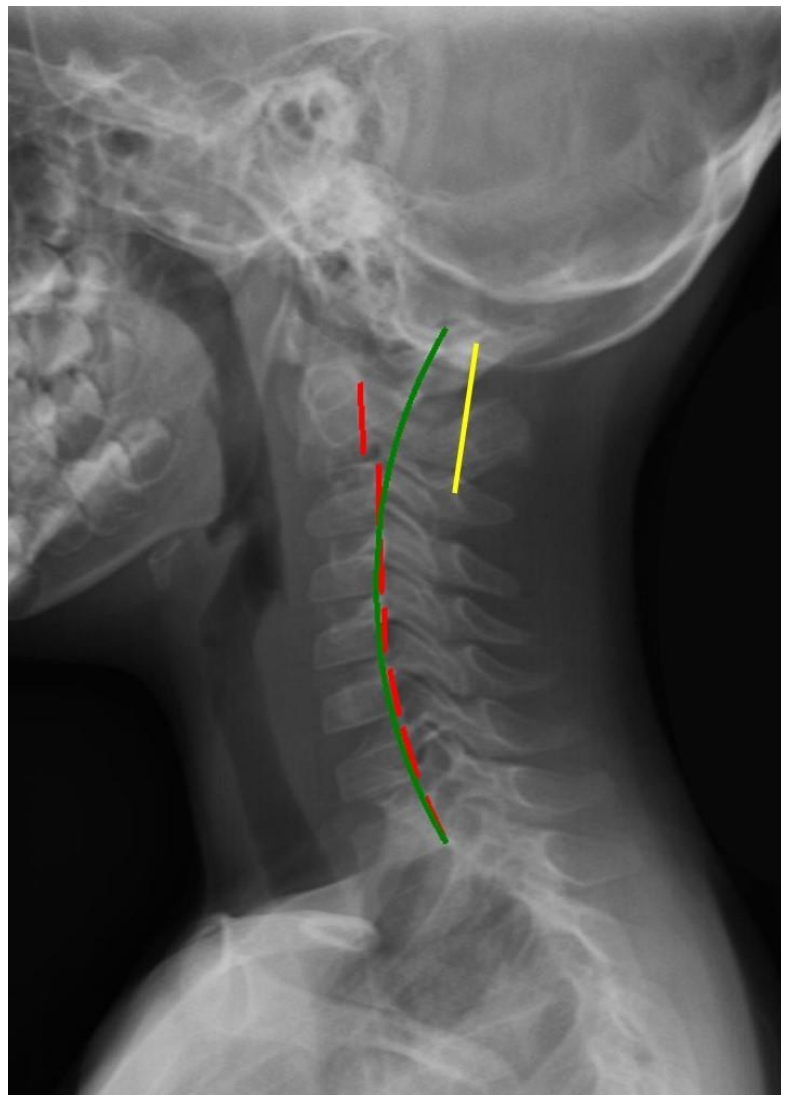

Figure 13 (left): NLC Radiograph of a Pediatric Patient with a C2-C3 Pseudosubluxation

Description: 5-year-old male with chief complaint of abnormal posture and no reported symptoms or reported history of trauma.

Image Features: The green line represents a normal, ideal cervical alignment. The red line represents the actual posterior tangent lines of the $\mathrm{C} 2-\mathrm{C} 7$ vertebrae. The yellow line represents the $\mathrm{C} 1-\mathrm{C} 3$ posterior cervical line (Swischuk line).

Findings: NLC image shows cervical curvature C2-C7 measures $-13.6^{\circ}\left(27.8^{\circ}\right.$ is ideal), Tz C2-C7 measures $11.9 \mathrm{~mm}$ ( $0.0 \mathrm{~mm}$ is ideal), $\mathrm{Tz} \mathrm{C} 2-\mathrm{C} 3$ measures $2.4 \mathrm{~mm}$ but qualifies as a C2-C3 pseudosubluxation instead of a CS because the C1C3 posterior cervical line (Swischuk line) passes through the C2 spinolaminar line, $|\mathrm{STz}| \mathrm{C} 3-\mathrm{C} 7$ measurements $<0.4 \mathrm{~mm}$ $(0.0 \mathrm{~mm}$ is ideal).

Technique: 30 mAs, 200 mA, 76 kVp, 72" FFD, CR at C4. 


\begin{tabular}{|c|c|}
\hline Spondylolisthesis & Summary \\
\hline Etiology & $\begin{array}{l}\text { - Translation of vertebra with respect to vertebra below } \\
\text { - Abnormal weight distribution, soft tissue laxity, and instability } \\
\text { - Excessive joint play and degeneration of the intervertebral disc } \\
\text { - Abnormal spinal alignment and positional loading of the cervical spine } \\
\text { - May present with neck pain, radiculopathy, or no symptoms }\end{array}$ \\
\hline Incidence & - 5.2 to $11 \%$ \\
\hline Gender Ratio & - Male:Female is $3: 2$ in grade 1 and $11: 5$ in grade 2 spondylolisthesis. \\
\hline Age Predilection & $\begin{array}{l}\text { - Increase in prevalence after } 60 \text { years } \\
\text { - } 5 \% \text { of } 0 \text {-20-year-olds; } 33.3 \% \text { of } 20 \text {-59-year-olds; } 66.7 \% \text { of } 60-99 \text {-year-olds }\end{array}$ \\
\hline Risk Factors & $\begin{array}{l}\text { - Increased age, sex, facet hypertrophy, cervical hypolordosis/kyphosis, anterior head translation, } \\
\text { cervical spondylosis/degeneration, history of cervical spine surgery } \\
\text { - Abnormal spinal alignment } \\
\text { - Correlation with cervicothoracic sagittal alignment factors }\end{array}$ \\
\hline Treatment & $\begin{array}{l}\text { - Spinal fusion surgery to stabilize } \\
\text { - Non-surgical methods include active physical therapy, education or counseling for exercising, } \\
\text { nonsteroidal anti-inflammatory drugs, homeopathic remedies, soft tissue massage, trigger point } \\
\text { therapy, spinal mobilization techniques to restricted areas, cryotherapy, and chiropractic }\end{array}$ \\
\hline Prognosis & - Degenerative condition unless the spine is stabilized \\
\hline Findings on Imaging & $\begin{array}{l}\text { - Most common levels are } \mathrm{C} 3-\mathrm{C} 4, \mathrm{C} 4-5 \text {, and } \mathrm{C} 5-\mathrm{C} 6 \text { followed by } \mathrm{C} 6-\mathrm{C} 7 \\
\text { - X-ray imaging shows extent of segmental translation } \\
\text { - Magnetic resonance imaging shows extent of soft tissue damage }\end{array}$ \\
\hline
\end{tabular}

Table 1: Summary table of cervical spondylolisthesis in the sagittal plane.

\begin{tabular}{|l|l|l|}
\hline & CS > 2.0 mm & CS > 3.5 mm \\
\hline Total & 73 & 8 \\
\hline With Head and(or) Neck Musculoskeletal Complaints & 22 & 2 \\
\hline $\begin{array}{l}\text { With Head and(or) Neck Musculoskeletal Complaints AND Mid-Back, Low Back, and(or) } \\
\text { Pelvic Musculoskeletal Complaints }\end{array}$ & 9 & 1 \\
\hline With ONLY Head and(or) Neck Musculoskeletal Complaints & 13 & 1 \\
\hline With ONLY Mid-Back, Low Back, and(or) Pelvic Musculoskeletal Complaints & 9 & 1 \\
\hline With NO Musculoskeletal Complaints & 42 & 5 \\
\hline
\end{tabular}

Table 2: Symptoms of pediatric patients with cervical spondylolisthesis. 


\begin{tabular}{|c|c|c|c|c|}
\hline $\begin{array}{l}\text { Differential } \\
\text { Diagnoses }\end{array}$ & Plain Radiography & $\begin{array}{l}\text { Magnetic Resonance } \\
\text { Imaging }\end{array}$ & $\begin{array}{l}\text { Computed Tomography } \\
\text { Myelography }\end{array}$ & Computed Tomography \\
\hline $\begin{array}{l}\text { Degenerative } \\
\text { Cervical } \\
\text { Spondylolisthesis }\end{array}$ & $\begin{array}{l}\text { - Upright, weight-bearing } \\
\text { lateral cervical view is } \\
\text { most appropriate for } \\
\text { detecting } \\
\text { spondylolisthesis. } \\
\text { - Lateral cervical flexion } \\
\text { and extension views } \\
\text { demonstrate cervical } \\
\text { instability. }\end{array}$ & $\begin{array}{l}\text { Most appropriate for } \\
\text { imaging spinal stenosis } \\
\text { or facet joint } \\
\text { arthropathy. } \\
\text { - Provides a detailed view } \\
\text { of the cervical spine, } \\
\text { spinal cord, and soft } \\
\text { tissue structures. }\end{array}$ & $\begin{array}{l}\text { Useful in assessing } \\
\text { spinal stenosis or nerve } \\
\text { roots and when } \\
\text { magnetic resonance } \\
\text { imaging is } \\
\text { contraindicated or } \\
\text { inconclusive. } \\
\text { - Provides a view of the } \\
\text { entire cervical spine } \\
\text { and is done in the } \\
\text { standing position } \\
\text { (accentuates spinal } \\
\text { stenosis). } \\
\end{array}$ & $\begin{array}{l}\text { - Useful when magnetic } \\
\text { resonance imaging and } \\
\text { computed tomography } \\
\text { myelography are } \\
\text { contraindicated or } \\
\text { inconclusive. } \\
\text { - Useful in assessing } \\
\text { spinal stenosis or nerve } \\
\text { roots and provides a } \\
\text { detailed view of the } \\
\text { facet joints. }\end{array}$ \\
\hline Cervical Fracture & $\begin{array}{l}\text { - Upright, weight-bearing } \\
\text { lateral cervical view is } \\
\text { most appropriate for } \\
\text { detecting } \\
\text { spondylolisthesis. } \\
\text { - Lateral cervical flexion } \\
\text { and extension views } \\
\text { demonstrate cervical } \\
\text { instability. } \\
\end{array}$ & & & \\
\hline $\begin{array}{l}\text { Cervical Canal } \\
\text { Stenosis }\end{array}$ & & $\begin{array}{l}\text { - Most appropriate for } \\
\text { imaging spinal stenosis } \\
\text { or facet joint } \\
\text { arthropathy. } \\
\text { - Provides a detailed view } \\
\text { of the cervical spine, } \\
\text { spinal cord, and soft } \\
\text { tissue structures. }\end{array}$ & $\begin{array}{l}\text { Useful in assessing } \\
\text { spinal stenosis or nerve } \\
\text { roots and when } \\
\text { magnetic resonance } \\
\text { imaging is } \\
\text { contraindicated or } \\
\text { inconclusive. } \\
\text { - Provides a view of the } \\
\text { entire cervical spine } \\
\text { and is done in the } \\
\text { standing position } \\
\text { (accentuates spinal } \\
\text { stenosis). }\end{array}$ & $\begin{array}{l}\text { - Useful when magnetic } \\
\text { resonance imaging and } \\
\text { computed tomography } \\
\text { myelography are } \\
\text { contraindicated or } \\
\text { inconclusive. } \\
\text { - Useful in assessing } \\
\text { spinal stenosis or nerve } \\
\text { roots and provides a } \\
\text { detailed view of the } \\
\text { facet joints. }\end{array}$ \\
\hline $\begin{array}{l}\text { Cervical Disc } \\
\text { Degeneration }\end{array}$ & & $\begin{array}{l}\text { Most appropriate for } \\
\text { imaging spinal stenosis } \\
\text { or facet joint } \\
\text { arthropathy. } \\
\text { - Provides a detailed view } \\
\text { of the cervical spine, } \\
\text { spinal cord, and soft } \\
\text { tissue structures. }\end{array}$ & & \\
\hline $\begin{array}{l}\text { Cervical Facet } \\
\text { Dislocation }\end{array}$ & $\begin{array}{l}\text { - Upright, weight-bearing } \\
\text { lateral cervical view is } \\
\text { most appropriate for } \\
\text { detecting } \\
\text { spondylolisthesis. } \\
\text { - Lateral cervical flexion } \\
\text { and extension views } \\
\text { demonstrate cervical } \\
\text { instability. } \\
\end{array}$ & & & \\
\hline $\begin{array}{l}\text { Cervical Facet } \\
\text { Arthropathy }\end{array}$ & & $\begin{array}{l}\text { - Most appropriate for } \\
\text { imaging spinal stenosis } \\
\text { or facet joint } \\
\text { arthropathy. } \\
\text { - Provides a detailed view } \\
\text { of the cervical spine, } \\
\text { spinal cord, and soft } \\
\text { tissue structures. }\end{array}$ & & $\begin{array}{l}\text { - Useful when magnetic } \\
\text { resonance imaging and } \\
\text { computed tomography } \\
\text { myelography are } \\
\text { contraindicated or } \\
\text { inconclusive. } \\
\text { - Useful in assessing } \\
\text { spinal stenosis or nerve } \\
\text { roots and provides a } \\
\text { detailed view of the } \\
\text { facet joints. }\end{array}$ \\
\hline
\end{tabular}

Table 3: Differential diagnosis table for cervical spondylolisthesis in the sagittal plane and appropriate imaging. 


\section{ABBREVIATIONS}

$>$ - Greater than

$\ell \mathrm{A}$ - the length of the segmental anterior translation in an anterolisthesis (a CS where the superior vertebra moves anterior to the inferior vertebra).

$\ell \mathrm{R}$ - the length of the segmental posterior translation in a retrolisthesis (a CS where the superior vertebra moves posterior to the inferior vertebra).

C1 - First Cervical Vertebra

C2-C3 - Second to Seventh Cervical Vertebrae

C2-C7 - Second to Seventh Cervical Vertebrae

$\mathrm{cm}-$ centimeter

CR - Central Ray

$\mathrm{CS}$ - Cervical Spondylolisthesis

$|\mathrm{CS}|$ - Absolute value (positive value) of cervical spondylolisthesis measurement

CT - Computed Tomography

FFD - Film Focal Distance

IVD - Intervertebral disc

$\mathrm{kg}$ - kilogram

$\mathrm{kVp}$ - kilovoltage peak

mAs - milliampere second

mm - millimeter

MRI - Magnetic Resonance Imaging

$\mathrm{n}$ - number of participants, subjects, or patients

NLC - Neutral Lateral Cervical

$\mathrm{STz}$ - Segmental translation in the z-axis/sagittal plane

$|\mathrm{STz}|$ - Absolute value (positive value) of segmental translation measurement in the $\mathrm{z}$-axis/sagittal plane

$\mathrm{Tz}$ - Translation in the $\mathrm{z}$-axis/sagittal plane

\section{KEYWORDS}

cervical spondylolisthesis; pediatric spondylolisthesis; cervical spine; radiography; vertebral subluxation; prevalence; epidemiology; cervical instability

\section{Online access}

This publication is online available at:

www.radiologycases.com/index.php/radiologycases/article/view/4280

\section{Peer discussion}

Discuss this manuscript in our protected discussion forum at: www.radiolopolis.com/forums/JRCR

\section{Interactivity}

This publication is available as an interactive article with scroll, window/level, magnify and more features.

Available online at www.RadiologyCases.com

\section{Published by EduRad}

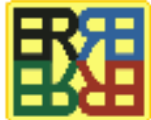

www.EduRad.org 